\title{
The Physiological Anatomy of the Periderm of Fossil Lycopodiales.
}

\author{
BY \\ MABEL H. KISCH, B.SC. \\ University of London, University College. \\ With Plate XXIV and twenty-seven Figures in the Text. \\ CONTENTS.

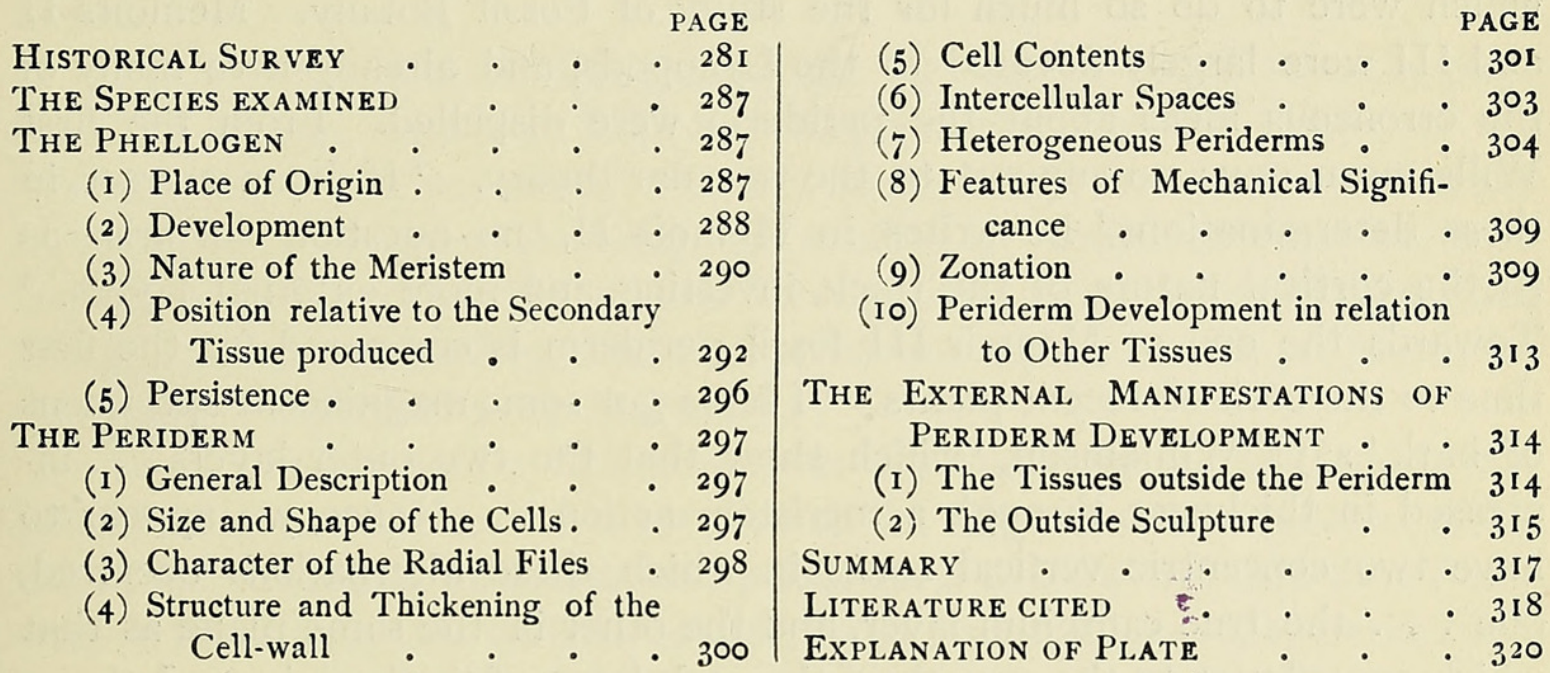

\section{Historical Survey.}

THE earliest reference to the periderm of fossil plants was made by Witham in his description of the classical specimen of Lepidodendron Harcourtii, found in $\mathbf{1} 832$. 'The tissue of the superficial layer', he writes, ' has a striking resemblance to that of the woody tissue of the Coniferae, the cellules being disposed in regular series and of a form approaching the hexagonal, but without indications of medullary rays.' ${ }^{1}$ This comparison with the wood of the Coniferae was repeated by Lindley and Hutton in their 'Fossil Flora', but they added that a vertical section showed that the meshes were ' merely sections of cellular tissue '.2

In I839 Brongniart's monograph on Sigillaria elegans ${ }^{3}$ was published, and in it appeared a more detailed and accurate description of the periderm under the name of the 'inner cortical zone'.4 Brongniart commented on

1 Witham (45).

3 Now known as S. Menardi or Brardi.
2 Lindley and Hutton (17), p. 47.

- Brongniart (8).

Annals of Botany, Vol. XXVII. No. CVI. April, 19ı3.] 
the absence of rays and pits, and drew attention to the characteristic appearance in radial section, which he explained as due to the uniform length of the cells in each row.

It was not till the work of Binney $(1862-75)$ that the periderm of fossil Lycopods received any further attention, ${ }^{1}$ with the exception of a paper by Dawes, in which the existence of a 'prosenchymatous zone' in a Halonial branch was noticed. ${ }^{2}$ Binney was the first to point out the presence of an 'outer radiating cylinder' in Stigmaria, as well as in Lepidodendron. He realized the secondary nature of the periderm, but he too fell into the error of believing it to be a vascular tissue, a 'pseudo-wood' ${ }^{3}$ and it was on these grounds that he based his support of Dawson's theory that Sigillaria was a hard-wooded tree, and not a hollow and succulent plant, ${ }^{4}$ though Dawson himself had referred only to the central axis. ${ }^{5}$

In $187 \mathrm{I}$ appeared the first of Williamson's great series of memoirs which were to do so much for the study of Fossil Botany. Memoirs II and III were largely devoted to the Lycopods, and already here many of the erroneous ideas about the periderm were dispelled. From the first Williamson gave no support to the vascular theory. 'If I am correct in these determinations,' he writes in Memoir II, 'no question can arise as to the cortical nature of the thick, investing, and more external layers.' 6 Towards the end of Memoir III fossil periderm is compared for the first time to the cork of recent plants. 'I have got some magnificent specimens of bark,' says Williamson, 'which show that the two outer layers ... increased in thickness through a meristem action.... Hence, we appear to have two concentric vertical zones in which these alternations occurred, one ... the true cambium layer, and the other in the same plane as that which contributes to the growth of the cork-layer of the bark.' $\ldots .^{7}$

In 1875 , three years after the publication of Memoir III, appeared the memoir on Sigillaria spinulosa by Renault and Grand'Eury, ${ }^{8}$ and this included a fairly detailed description of its peculiar Dictyoxylon cortex, as it appears in transverse and longitudinal sections. Three years later, Williamson, in his ninth Memoir, described what he thought was an English example of the same species, ${ }^{9}$ and showed that the cells of the meshes were in a state of active division, and that there were signs of similar activity in the peripheral parenchyma. He also brought forward a theory as to the origin of the tissue, viz. that it was developed from a meristematic layer on the exterior; while in function he considered it similar to the 'phellem, layer of living exogens' ${ }^{10}$

1 Binney (4), (5), (6), (7).

3 Binney (5), p. $59^{2}$.

5 Dawson $(10)$.

7 Williamson (38), pp. 31 3-I 4 .

${ }^{9}$ It was really a Stigmaria.
2 Dawes (9).

4 Binney (5), p. 597.

6 Williamson (37), p. 203.

8 Renault and Grand'Eury (22).

10 Williamson (39), p. 355 . 
Renault repeated his original observations on Dictoxylon cortex in his 'Structure comparée de quelques tiges,' \&c. (I879) ${ }^{1}$ under Lepidodendron rhodumnense, which is very similar to Sigillaria spimulosa, but he gare no explanation as to the origin or development of the assise subereuse. On the other hand, it was just this aspect of the subject which appealed most to Williamson, and he returned again to it in his Memoir $\mathrm{X}$ in reference to Lepidodendron Wunschianum. 'The bast tissues', he writes, 'increase in thickness with the stem, ... but no additional light is thrown on the physiological question, viz. whether the additions .... are due to a plane of genetic activity on its external or its internal surface.' ${ }^{2}$ In Memoir XI he added that the 'prosenchymatous zone' of Lepidodendron selaginoides, which he refers to later for the first time as periderm, appears under the leaf-bases in the form of detached arcs, and that the meristematic layer was on the outside of the tissue, owing to 'regular continuity of its peripheral border'. ${ }^{3}$

Some years later, in his monograph on Stigmaria, Williamson gave what he always considered his most complete notice of the history of the development of the periderm. ${ }^{4}$ In this he described the outer layers of the prosenchymatous zone as being in a state of active division by both horizontal and vertical septa, and he explained the somewhat disturbed arrangement by concluding that the meristematic zone formed prosenchyma internally and parenchyma externally.

In Solms-Laubach's 'Einleitung in die Paläophytologie', which was published in German in the same year as the Stigmaria monograph (1887), the terms phellogen, periderm, and phelloderm are for the first time freely used in describing the fossil Lycopods, but it is explained that periderm is not to be taken in its physiological sense, since the leaf-bases beyond it do not dry up. ${ }^{5}$ Solms locates the phellogen near the outer margin in Lepidodendron selaginoides, but, contrary to Williamson, on the inner margin in Stigmaria.

In I89I appeared Bertrand's memoir on Lepidodendron Harcourtii. ${ }^{6}$ Here the periderm is described as arising from a diffuse continuous cambium on the inner boundary of the tissue, though there are indications that the most delicate elements were towards the centre. Bertrand refers to the periderm under the name of cork, but he points out that it had not yet caused exfoliation.

Bertrand's work was followed the next year by Hovelacque's monograph on Lepidodendron selaginoides. ${ }^{7}$ Hovelacque denies that the secondary cortical tissue is a phelloderm, as had been stated by Williamson and

1 Renault (19).

3 Williamson (41), pp. 28 5-6.

5 Solms-Laubach (30).

7 Hovelacque (15).
2 Williamson (40), p. 498.

4 Williamson (43).

6 Bertrand (3). 
confirmed by Solms-Laubach. He considers it a true periderm, derived from a diffuse phellogen on the inner surface, and he explains the layer of compressed cells, regarded as phellogen by Solms, as one of the zones of thinner walled, easily squashable cells which alternate with the ordinary prosenchyma in $L$. selaginoides.

In 1893 Hick noted the presence of a periderm zone in his new fossil Xenophyton radiculosum, ${ }^{1}$ and in the same year appeared the last of Williamson's Memoirs, Part XIX, in which he brings further support for the conclusions of his Stigmaria monograph in the structure of a Halonial branch of Lepidophloios, where the 'meristemic zone' is figured between the outermost cortex and the prosenchyma. ${ }^{2}$ Williamson again summed up the results of his work on the tissue in a paper for the Manchester Literary and Philosophical Society. ${ }^{3}$

Renault's last important work was more or less contemporaneous with these last papers of Williamson, for the 'Atlas' of his 'Flore fossile d'Autun et d'Épinac' was published in 1893 and the 'Texte' in 1896.4 Two more species, Sigillaria lepidodendrifolia and Lepidodendron esnostense, are here described as having Dictyoxylon cortex similar to that of S. spinulosa and L. rhodumnense. In 1897 , Renault and Roche described another species preserved in the Syringodendron condition with a cortex very like that of Lepidodendron esnostense. ${ }^{5}$ They considered that it had undergone successive decortications along the concentric zones, and that it had a true cork layer renewed from the inner surface, and excluding gaseous interchange, which was provided for by the enlarged and persistent parichnos.

The next important addition to the knowledge of the periderm of the fossil Lycopods was made in 1900 in Seward and Hill's paper on a Lepidodendroid stem from Dalmeny (Williamson's L. Wunschianum), which had a band of secondary cortex several centimetres thick. ${ }^{6}$ This is considered by the authors to be phelloderm, but it is not stated if there is any direct evidence of the position of the phellogen. The periderm is characterized by the presence of concentric bands of light-coloured cells, which are described as secretory in function. Seward and Hill are the first to point out the presence of intercellular spaces in the periderm of this species, and give more consideration than previous writers to the functions of the tissue, emphasizing its mechanical usefulness at the periphery.

In I900 was published also the first edition of Scott's 'Studies'.? Scott states that in Lepidodendron Harcourtii the development of the periderm took place on both sides of the initial layer, but he reserves the type of $L$. selaginoides for a more detailed account of the tissue. Here

1 Hick (14). Xenophyton is regarded by Weiss as the Stigmaria of Lepidodendron fuliginosum.

2 Williamson (42).

4 Renault (21).

${ }^{6}$ Seward and Hill (29).

3 Williamson (44).

5 Renault and Roche (23).

7 Scott (24). 
the view supported is that the phellogen was just inside the leaf-bases, and that the corky nature, even of the little tissue on the outer side, is very doubtful. With regard to Stigmaria, Scott agrees with Solms and differs from Williamson in believing that remains of the phellogen can be traced on the inner edge, but that the tissue was not impermeable. He gives a brief description of the periderm of species of Sigillaria, and points out that in all these plants the functions of the secondary cortex were probably very different, and much more important than in recent vegetation.

The periderm of Lepidophloios fuliginosus next received attention in the paper by Weiss on a Halonial branch of the species. ${ }^{1}$ Here no phellogen layer can be distinguished, though the tissue is regarded as being probably phelloderm, but Weiss considers it (unlike the periderm of the Dalmeny specimen) a closely-set, protective layer which would prevent the passage of air to the interior tissues; and, in a paper on the parichnos written a few years later, he says, 'A respiratory passage through the dense outer cortex and the impervious periderm would seem to be an essential requirement of the Lepidodendroid stem.' ${ }^{2}$

In I 906 Seward noted the formation of a wound periderm in Lepidodendron aculeatum, ${ }^{3}$ and Scott the presence in places of a second periderm in L. obovatum, ${ }^{4}$ but the next detailed account of the tissue is to be found in 1907 in Arber and Thomas's paper on Sigillaria scutellata. ${ }^{5}$ Here the secondary cortex forms the bulk of the ribs of the species, and is regarded as phelloderm, because the tangential walls of the outer layers are closer together and thinner than those of the more internal elements, and the parenchyma outside remains unchanged. In the same year an account was given by Watson of his new species, Lepidodendron Hickii, which had been included in the L. Harcourtii of Williamson. One specimen shows the first beginnings of the periderm, and it is stated that 'the central cell becomes the meristem and cuts off new cells on both sides' $;{ }^{6}$ but that in older sections it is impossible to locate the phellogen.

In 1908 Gordon described another new species, Lepidophloios Scottii, in the periderm of which there are zones of clear cells alternating with zones filled with dark material, which are taken as an indication of some sort of periodic rest. ${ }^{7}$ In 1908 also, besides a paper by Weiss on a Stigmaria with centripetal wood possibly belonging to Bothrodendron, ${ }^{8}$ where the thinwalled periderm with its outer cells tangentially extended is taken as evidence of Stigmarian nature, there was published the second edition of Scott's 'Studies'. In this, however, little is added to the original account of the periderm of the fossil Lycopods beyond bringing the book up to date by references to recent work.

1 Weiss (33).
4 Scott (25).
7 Gordon (12).
${ }^{2}$ Weiss (35), p. 7 .

${ }^{5}$ Arber and Thomas (1).

8 Weiss (36).
${ }^{3}$ Seward (27).

${ }^{6}$ Watson (32), p. 9. 
Three papers remain to be considered. In a note on the cortex of Sigillaria mamillaris, Arber and Thomas showed that the periderm was very similar to that of $S$. scutellata, ${ }^{1}$ while Zalessky in 1909 gave a detailed account of the periderm in specimens referred by him to Lepidodendron aculeatum $^{2}$ and Sigillaria Boblayi. ${ }^{3}$ In the former there are in one specimen peculiar wedge-shaped groups of thinner-walled, lighter-coloured cells, and in both species the tissue is assumed to be phelloderm owing to the presence of tangentially extended cells, with the tangential thinner than the radial walls, at places on the outer border. ${ }^{4}$ In a further paper published in I9II, Zalessky describes shortly the periderm of his Lepidodendron obovatum, which is probably identical with $L$. Hickii, Watson. ${ }^{5}$

In I910 appeared the second volume of Seward's 'Fossil Plants', ${ }^{6}$ in which there is a full account of the periderm in various species of Lepidodendron, Sigillaria, Stigmaria, and Bothrodendron. Special stress is laid upon the indication of the position of the phellogen by the line along which splitting tends to take place. As a result any secondary cortex which has split off with the leaf-bases (frequently found in Lepidophloios, \&c.) is regarded morphologically as true periderm, though it is uncertain whether or no it agreed with the cork of recent plants. By this means Seward locates the phellogen in L. vasculare (selaginoides), L. fuliginosum, $L$. Harcourtii, and Lepidophloios, in all of which he finds the tissue is mainly thick-walled phelloderm.

Following the same test for the position of the phellogen in Stigmaria, Seward considers that in young specimens all the periderm is on the outer side of the phellogen, but that it is permeable and not of the nature of cork ; that after a time phelloderm is formed on the inner side, and in old specimens constitutes the bulk of the secondary tissue. The zoning of the periderm of L. selaginoides and L. Wunschianum, and possibly of Stigmaria, is explained as due to the presence of secretory strands.

Seward comments on the great mechanical importance of the periderm, and draws special attention to the effect of its development on the external appearance. The older specimens of $L$. selaginoides, $L$. Wunschianum, $L$. brevifolium, and Sigillaria are all described as having thrown off their leaf-cushions and as possessing fissured bark.

The amount of space devoted in this volume to the consideration of the periderm of the fossil Lycopods compared to that in other text-books may be taken as some measure of the increase of knowledge of the tissue in recent years.

1 Arber and Thomas (2).

3 The S. mamillaris of Arber and Thomas.

${ }^{5}$ Zalessky (47).
${ }^{2}$ Not the same as Seward's L. aculeatum.

4 Zalessky (46).

${ }^{6}$ Seward (28). 
The Species examined.

The present paper is based on an investigation of the material in the collections at University College, London, and, by kind permission of Dr. A. Smith Woodward, of that in the Williamson Collection at the Natural History Museum. All the forms are British with the exception of Sigillaria spimulosa, which comes from Autun.

The following species showing a development of periderm have been examined :

Lepidodendron selaginoides (vasculare)

Harcourtii

Hickii

brevifolium (Veltheimianum)

intermedium

obovatum ${ }^{1}$

L. (Lepidophloios) Wunschianum

$\begin{array}{ll} & \text { fuliginosum } \\ & \text { Scottii }\end{array}$

Lepidodendron sp.

Lepidophloios sp.

Sigillaria scutellata

" reniformis

" organum

" elegans

„ tesselata

" sp. (Eusigillariae)

" spinulosa

Bothrodendron mundum

Stigmaria ficoides

" of Bothrodendron

" sp.

The specimens examined of Lepidodendron aculeatum, parvulum, and macrophylhim ${ }^{2}$ show no periderm.

\section{The Phellogen.}

\section{(I) Place of Origin.}

In all cases periderm formation originates in the outer cortex, from a zone of cells which may be situated

(a) almost immediately within the leaf-bases, with one to seven or so layers of primary cortex outside, as in

$$
\begin{array}{cl}
\text { Lepidodendron } & \text { selaginoides } \\
, & \text { brevifolium } \\
, & \text { intermedium } \\
, & \text { obovatum } \\
, & \text { Wunschianum }
\end{array}
$$

Lepidophloios sp.

All the ribbed Sigillariae

or (b) deeper in the outer cortex (about fifteen to thirty layers), as in

Lepidodendron fuliginosum

$\begin{array}{ll}" & \text { Scottii } \\ " & \text { Harcourtii } \\ " & \text { Hickii }\end{array}$

Lepidophloios sp.

Stigmariae.

1 This species is not considered by Zalessky to be the true L. obovatum, Sternberg.

2 The specimen shown in Text-fig. I, B, may possibly be L. macrophyllum. 
In Bothrodendron the periderm arises immediately within the radial primary cortex.

\section{(2) Development.}

The first beginnings of the phellogen may be seen in a few of the
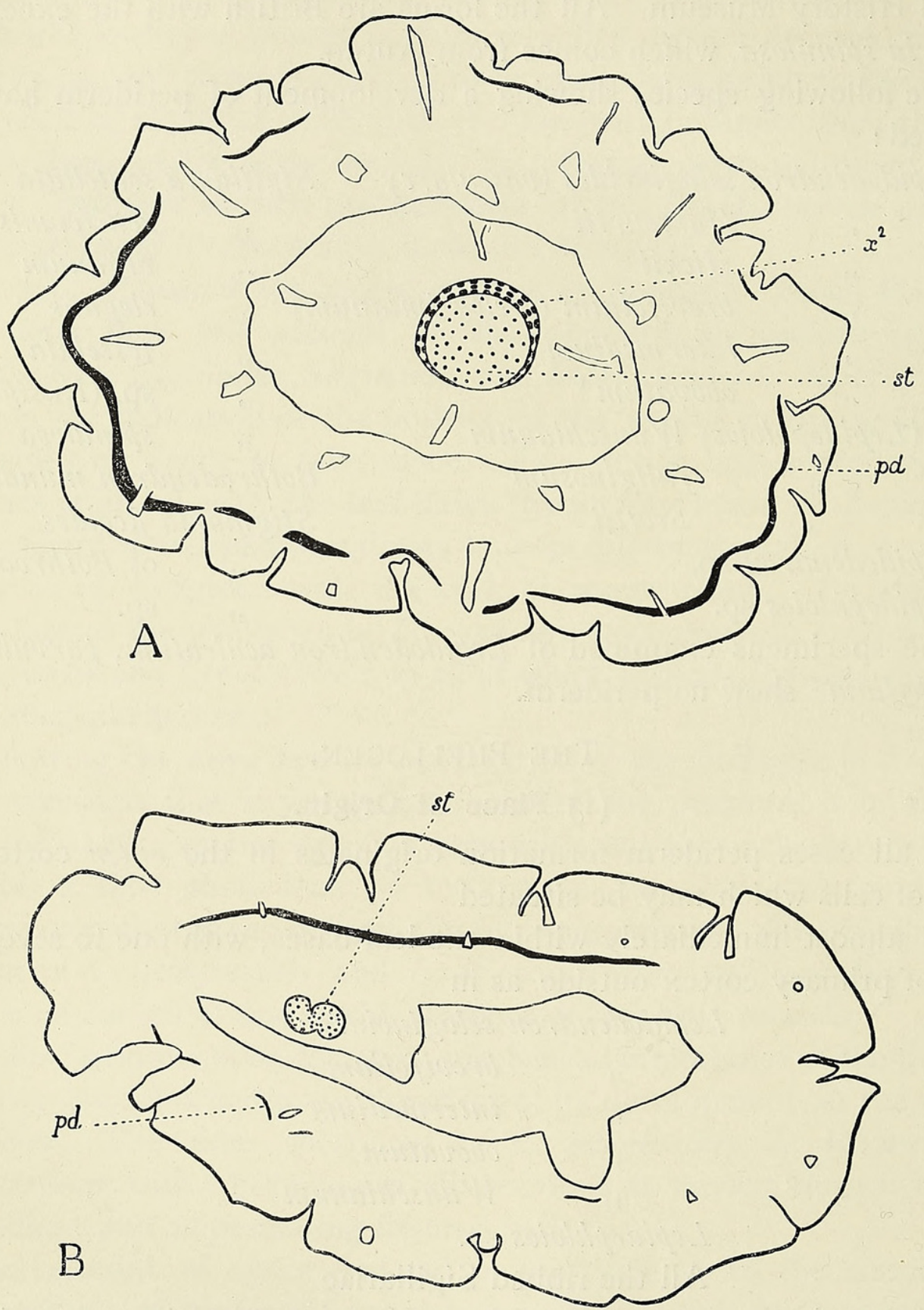

TeXT-FIG. I. Diagrammatic transverse sections to show first beginnings of periderm formation. A, Lepidodendron selaginoides. Will. Coll., $34^{2} . \times 9 . \quad \mathrm{B}$, Lepidodendron $\mathrm{sp}$. The developing periderm, $p d$, is shown in black; st, stele; $x^{2}$, secondary wood. Will. Coll., 1922 E. $\times 5$.

younger specimens. It develops in detached areas round the stem, but not, as described by Williamson ${ }^{1}$ and Hovelacque, ${ }^{2}$ in regular arcs under each

1 Williamson (41), p. 286, Pl. XLVII, Fig. I. In the specimen figured the periderm really extends all round the stem, but is more strongly developed under the leaf-bases.

${ }^{2}$ Hovelacque (15), p. I 58 , 
leaf-base. In Lepidodendron selaginoides and an undetermined Lepidodendron species these areas appear to be quite irregular in position (Text-fig. I, A and $\mathrm{B})$, but in another young twig they show a tendency to start from the middle of some of the leaf-bases (Text-fig. 2, A). In Bothrodendron mundum the secondary tissue is more regular in development, arising almost all round the stem at the same time (Text-fig. 2, B).
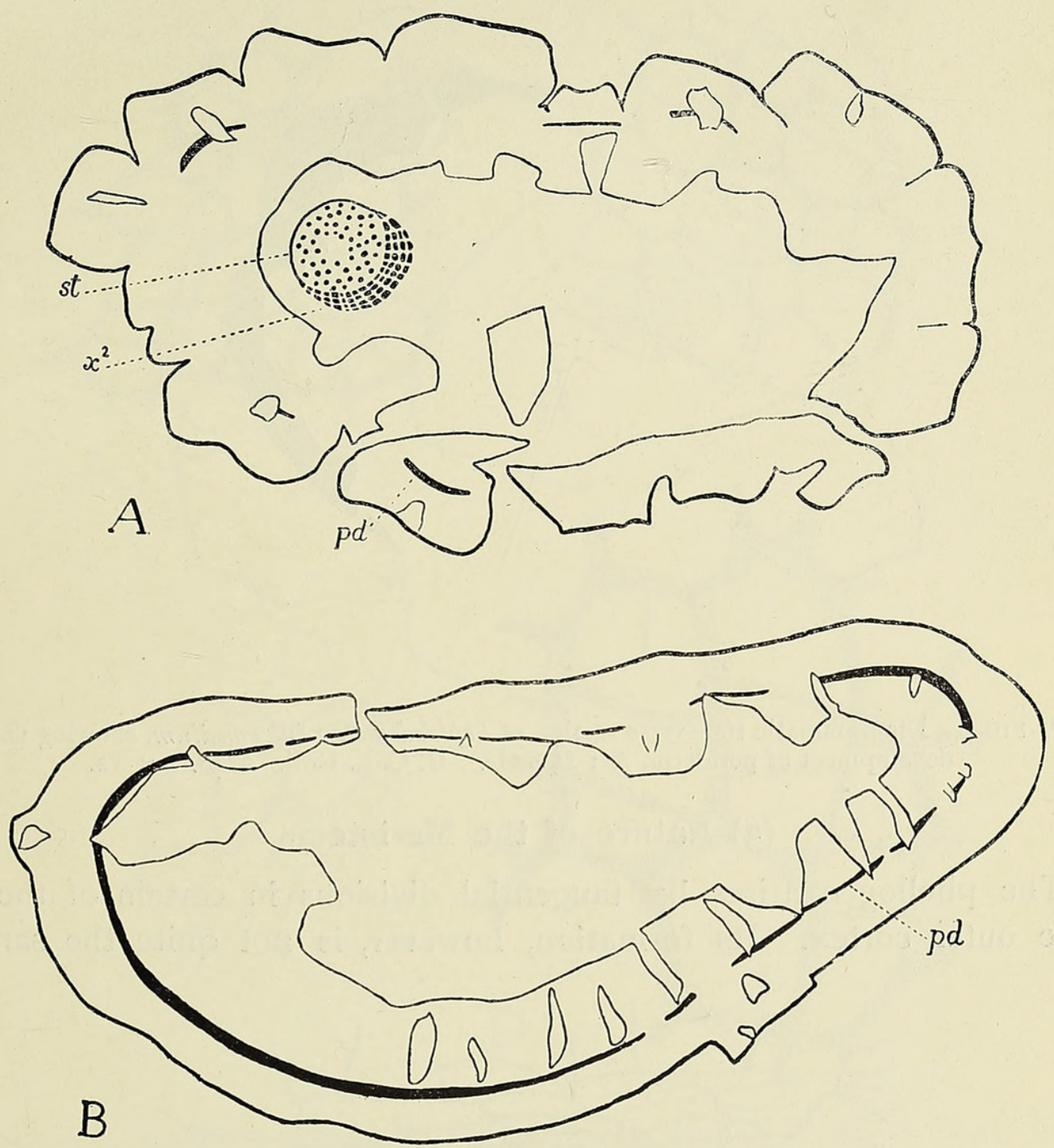

TEXT-FIG. 2. Diagrammatic transverse sections to show first beginnings of periderm formation. A, Lepidodendron sp. (selaginoides?). U. C. L. Coll., A or I. B, Bothrodendron mundum. $p d$, periderm; st, stele; $x^{2}$, secondary wood. U. C. L. Coll., A or $4 . \quad \times$ I 2.

The developing meristem gradually extends until a complete cylinder is formed, but one or two gaps may remain for some time, as in Lepidodendron Hickii ${ }^{1}$ and L. fuliginosum, and as a result of its irregular origin the secondary tissue produced is, at any rate at first, also irregular in thickness. Thus, in the specimens shown in Text-fig. I, ten layers of periderm cells have already been formed in one place in $\mathrm{A}$, and in $\mathrm{B}$ fourteen layers.

1 Noticed first by Williamson (42, p. 7 . 
Watson noted that in Lepidodendron Hickii the phellogen was not yet formed all the way round, though part of the periderm was twenty cells thick ; ${ }^{1}$ while in a specimen of Lepidodendron intermedium there is an arc of secondary tissue which is thirty-five cells thick in the centre, but formed only on one side of the stem (Text-fig. 3).

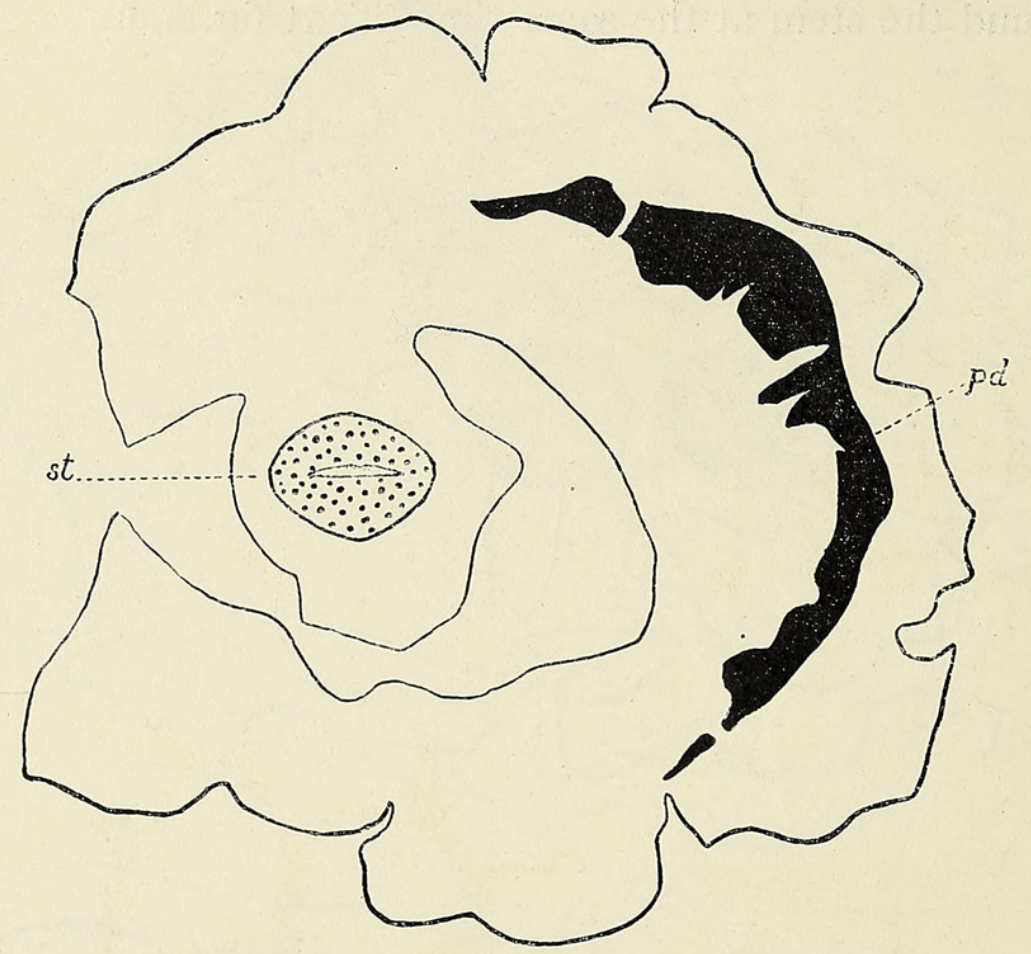

TEXT-FIG. 3. Diagrammatic transverse section of Lepidodendron intermedium, showing unequal development of periderm, $p d$; st, stele. U. C. L. Coll., A $48 . \quad \times 12$.

\section{(3) Nature of the Meristem.}

The phellogen arises by tangential divisions in certain of the cells of the outer cortex. Its formation, however, is not quite the same as

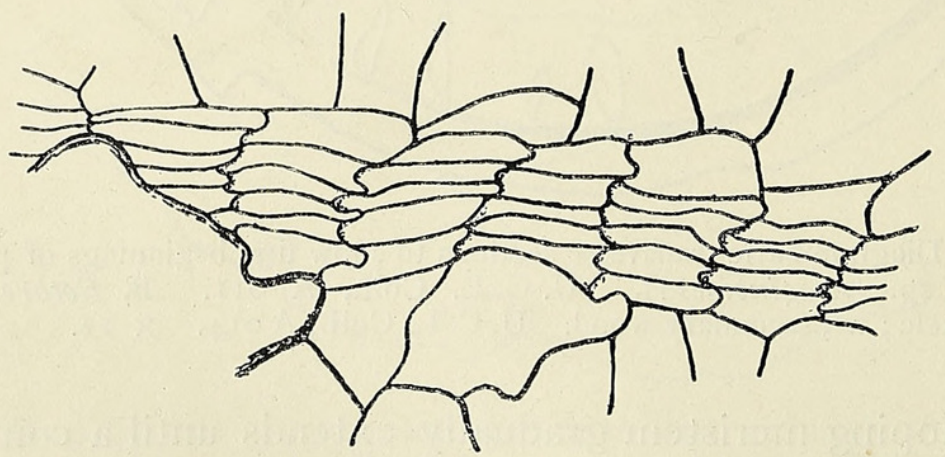

TeXt-FIG. 4. Lepidodendron selaginoides. Transverse section from the outer cortex showing the formation of the phellogen. Will. Coll., $34^{2} . \quad \times 26_{5}$.

is commonly found in recent plants, as it does not as a rule form a single continuous layer of meristematic cells, the products of which all pass directly into permanent tissue. The most regular case found is that of 
Lepidodendron selaginoides, where apparently a single layer of cells starts to divide (Text-fig. 4), but even here it seems probable that some of the secondary elements formed sometimes divide again. Text-fig. 4 shows the typical appearance of the flattened, thin-walled cells of the phellogen.

In other cases, as in Lepidodendron Hickii, Bothrodendron, and some young Lepidodendron species, the phellogenetic divisions may clearly be
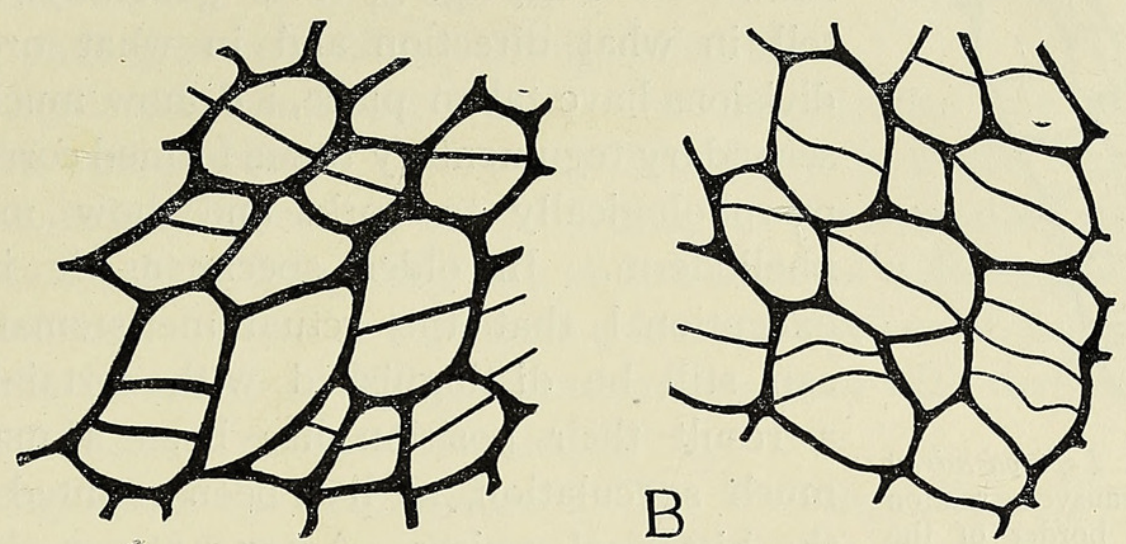

A
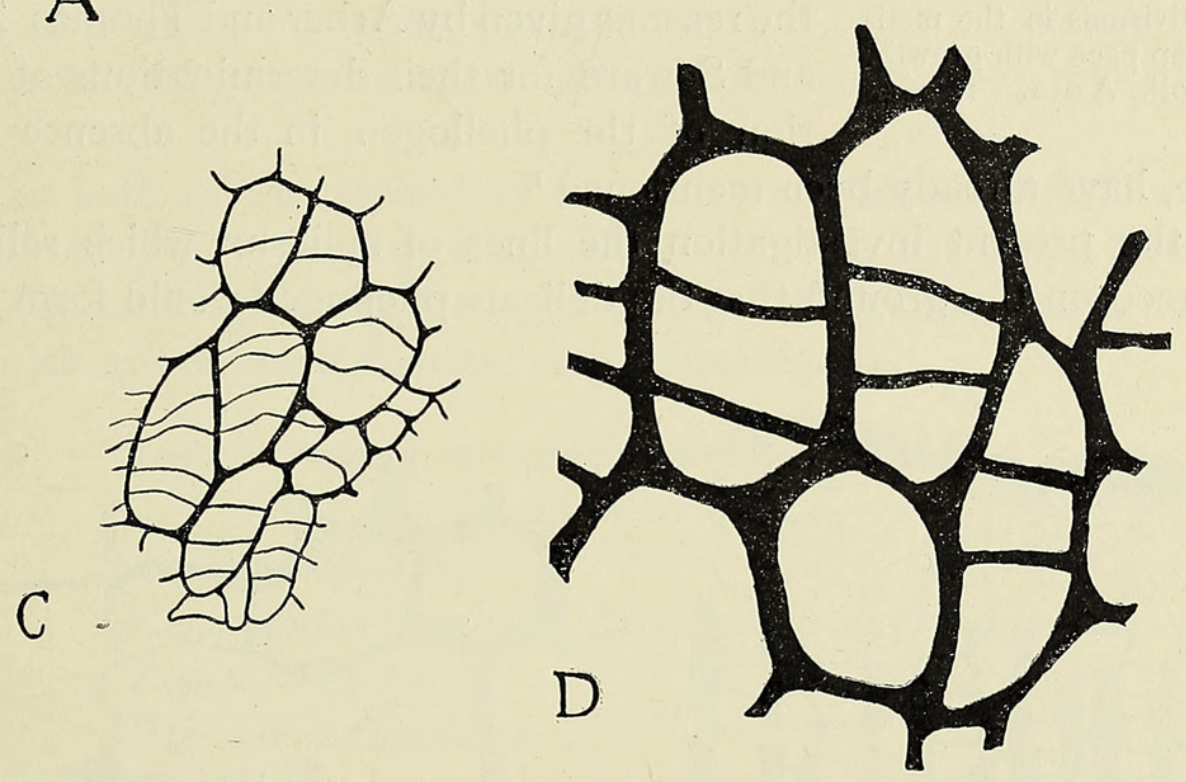

TEXT-FIG. 5. Transverse sections showing phellogenetic divisions starting in several layers of cells. A, Lepidodendron sp. Will. Coll., I922 E. B, Lepidodendron Hickii. Will. Coll., $380 \mathrm{~b}$. C, another Lepidodendron sp. U.C.L. Coll., A 49. D, Bothrodendron mundum. U.C. L. Coll., A or 4. Slightly diagrammatic. $\times 26_{5}$.

seen starting in several layers of cells (Text-fig. 5), sometimes in two cells on the same radius. ${ }^{1}$ The periderm of other species, of which there are no young examples, appears to have been similarly derived from this type of phellogen.

1 Watson (loc. cit.) noted this in L. Hickii, and thought it might mark the beginning of a secretory passage, but there seems no reason to suppose this, especially as no such passages have been found in this species. 
As is to be expected, the meristem keeps pace with the growth of the circumference by means of radial divisions (Text-fig. 6).

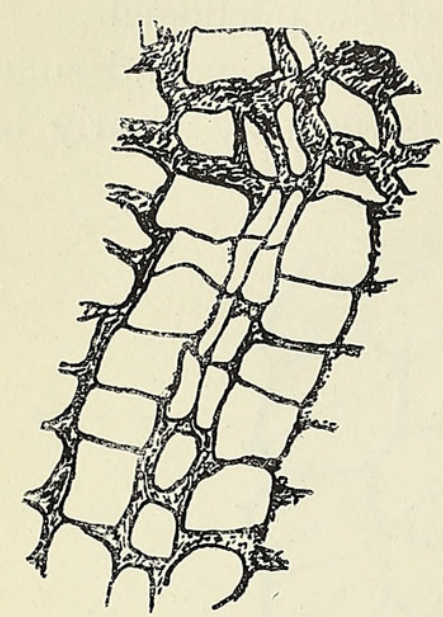

TeXT-FIG. 6. Lepidodendron selaginoides. Transverse section from the outer border of the periderm, showing files formed by radial divisions in the meristem to keep pace with growth. U. C. L. Coll., A or2. $\times 26_{5}$.

\section{(4) Position relative to the Secondary Tissue produced.}

Even in young specimens, such as those shown in Text-fig. 5, it is generally hard to tell in what direction and in what order the divisions have taken place, i. e. how much of the secondary tegumentary tissue formed corresponds morphologically to cork, and how much to phelloderm. In older specimens it is quite exceptional that the actual meristematic cells can still be distinguished with certainty. As a result their position has been a matter of much speculation, as has been pointed out in the historical review. Among recent observers, the reasons given by Arber and Thomas, Zalessky, and Seward for their determinations of the position of the phellogen, in the absence of direct evidence, have already been mentioned. ${ }^{1}$

In the present investigation the lines of split, on which reliance has been placed on the ground that the delicate phellogen would form a natural
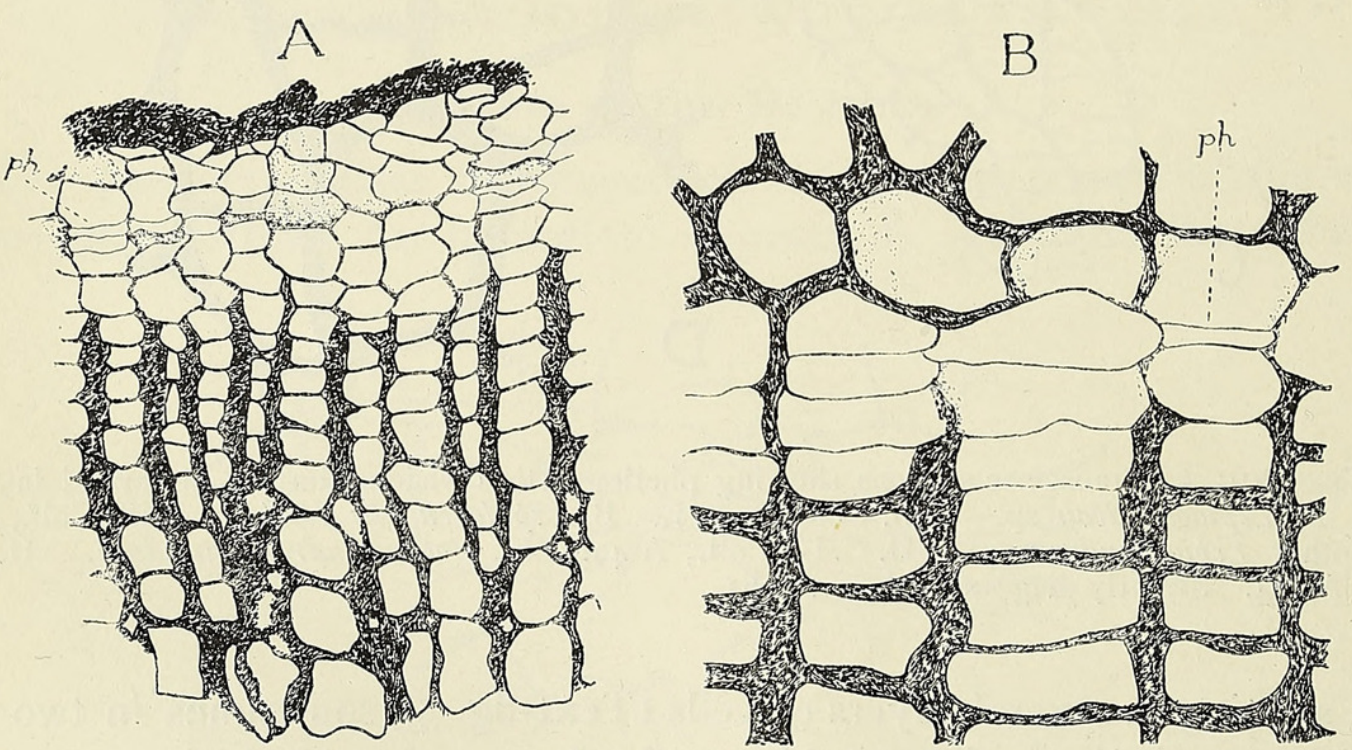

Text-Fig. 7. A, Lepidodendron selaginoides. U. C. L. Coll., A or 2. B, Sigillaria sp.

Will. Coll., ${ }_{5} 6$. Transverse sections in the periderm showing the phellogen, $p h . \quad \times 26_{5}$.

plane of weakness in the stem, ${ }^{2}$ have been taken into consideration; but in the specimens examined the position, except in Lepidodendron selaginoides

$$
1 \text { Loc. cit. }
$$

2 Seward (28), pp. I07, I I 5 , \&c. 
and some Stigmariae, was rarely at all constant, partly perhaps a consequence of the phellogen frequently not forming a regular and continuous line of cells. Reliance has not been placed on the size or flattened appearance of some of the cells, unless accompanied by less thickness of the walls, and where the probable position of the phellogen is indicated, this has in all cases been coupled with the absence of any signs of it in other parts of the tissue.

The phellogen can still be distinguished in

(a) Lepidodendron selaginoides. In this species the phellogen is sometimes well preserved, as at $p h$ in Text-fig. $7, A$, where the thin-walled dividing cells may be clearly seen. Nearly all the secondary tissue formed is phelloderm, there being only one or two rows of cells on the outer side of the meristem. In older examples a few more layers of cells may be cut off towards the exterior. This determination agrees with that arrived at by nearly all observers except Hovelacque. ${ }^{1}$

(b) Sigillaria sp. (Rhytidolepis). The dividing cells are here found on the outer border of the secondary tissue, which therefore may be regarded as entirely phelloderm (Text-fig. $7, \mathrm{~B}$ ).

In the following species there are indications of the position of the phellogen :

(a) The bulk of the secondary tissue appears to be phelloderm, with possibly one to four or five layers of cells formed on the outer side of the phellogen, for, although there are signs of recent divisions, it cannot be said exactly which are the meristematic cells (Text-fig. 8).

\section{Lepidodendron intermedium}

Lepidodendron sp. obovatum

Lepidophloios (type of Lepidodendron fuliginosum)

Lepidophloios sp.

Sigillaria scutellata

Sigillaria elegans

Sigillaria sp.

Arber and Thomas came to the same conclusion about the position of the phellogen in Sigillaria scutellata, ${ }^{2}$ and this is now further supported by the specimen shown in Text-fig. 7, B, which also belongs to the Rhytidolepis section. It should be noted that in all the ribbed Sigillariae the periderm is split off internally.

In the Lepidophloios from the Williamson Collection (C. N. 1955) shown in Text-fig. 8, A, this determination does not agree with that of Seward, who states for a similar specimen, consisting of leaf-bases and 
periderm, that the section had split off along the phellogen, so that the secondary cortical tissue preserved was formed on its outer side. ${ }^{1}$

(b) Stigmariae. The periderm of the Stigmariae presents at least two distinct types.

Type I. The periderm is fairly regular in appearance(Pl. XXIV, Fig. I), and seems to have been developed on the outer side of the phellogen. Only part of the periderm is generally preserved, and there are cambiallooking cells along its inner margin (see Text-fig. 9, A, ph). When, in rare cases, the whole of the periderm is present, the inner layers are seen to consist of very delicate and thin-walled cells which pass imperceptibly

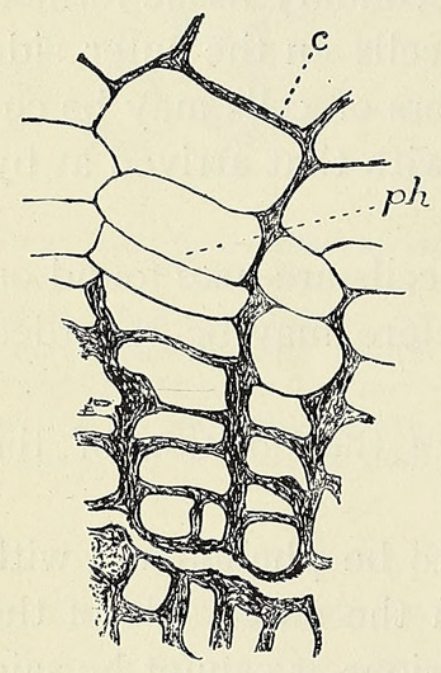

A

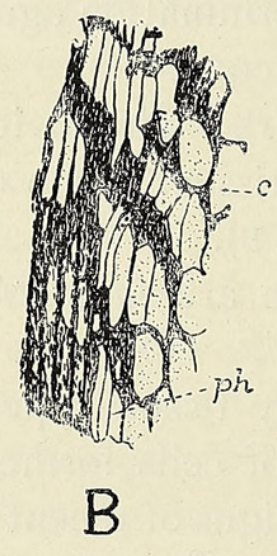

TEXT-FIG. 8. Sections showing indications of the position of the phellogen near the outer margin of the periderm. A, transverse section of Lepidophloios sp. Will. Coll., I955. B, radial section of Lepidodendron fuliginosum. U.C.L. Coll., A 33. C, transverse section of Sigillaria elegans. ph, phellogen; $c$, cortex outside periderm. U.C.L. Coll., E 5 a. A and C $\times 265$, B $\times 90$.

into the primary cortex. This is shown in Pl. XXIV, Fig. I. At $x$ a cell may be seen which has just divided.

Type 2. The periderm consists of a very irregular, wide-celled outer portion (Pl. XXIV, Fig. 2, a), of which many of the cells retain the power of division and which may receive additions from the division of cells of the outer cortex, and a more regular and smaller-celled internal portion (P1. XXIV, Fig. 2, b). This latter, which may greatly exceed the outer portion in thickness, is usually broken off abruptly on the inner side. In this type, though a disorganized band of cells is all that can generally be distinguished, the phellogen is probably at the junction of the two different kinds of tissue (Pl. XXIV, Fig. 2, ph), and forms the wide cells to the exterior and the narrower files on its inner surface by means of further radial divisions. Occasionally these divisions may lapse, and a wide-celled file extend some

\footnotetext{
1 Seward (28), p. Iog.
} 
way on the inner side of the supposed phellogen line (see Text-fig. 20, B). Text-fig. 9, B, shows signs of the phellogen in one of these wide-celled Stigmariae in which none of the inner portion of the periderm is preserved.

This determination agrees in the main with that of Seward, except that he considers the first type as a younger stage of the second ${ }^{1}$ (but the specimen of type I shown in Pl. XXIV, Fig. I, for example, has more wood than the specimen of type 2 shown in Pl. XXIV, Fig. 2), while it would also reconcile the views of Solms ${ }^{2}$ and $\mathrm{Scott}^{3}$ that the phellogen was on the inner side of the periderm, inferred from type 1 , and of William-
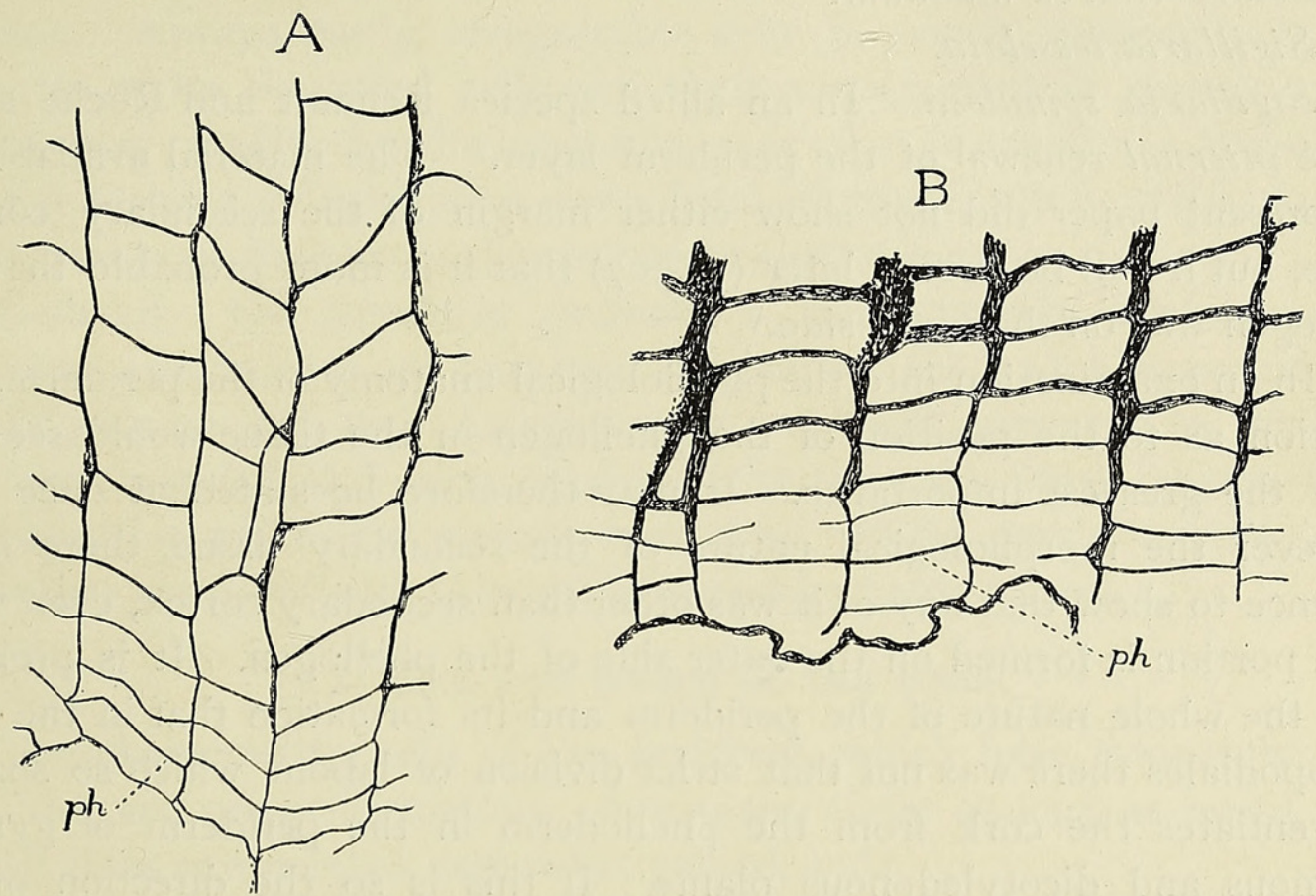

TEXT-FIG. 9. Transverse sections showing indications of the phellogen, $p h$, in Stigmariae: A, type I. Will. Coll., 764. B, type 2. U.C. L. Coll., CC $7 \mathrm{~h}$. The tissues on the inner side are not preserved. $\times 26_{5}$.

son ${ }^{4}$ that it was near the outer margin, inferred from specimens of type 2 with a large development of the regular inner portion of the tissue.

In the following species no satisfactory indications of the position of the phellogen have been found during the present investigation, but in certain cases other observers have made comments as to its position, and these are given below:

Lepidodendron Harcourtii and Hickii. Scott ${ }^{5}$ and Seward ${ }^{6}$ consider that the phellogen is near the centre of the periderm. Bertrand thought it was on the inner side. ${ }^{7}$

Lepidodendron brevifolium. There is some indication that the phellogen was near the outer margin of the secondary tissue, where there

\footnotetext{
1 Seward (28), pp. 243-4.

3 Scott (24), p. 247, 2nd ed.

5 Scott (24), p. I 39 .

7 Bertrand (3), p. 86.
}

2 Solms-Laubach (30), p. 274.

4 Williamson (43), p. 2 I.

6 Seward (28), p. I6I, Fig. I 79. 
may be seen rather delicate-looking cells and traces of broken cellwalls.

Lepidodendron Wunschianum. Seward and Hill assumed that the secondary cortical tissue was all phelloderm, ${ }^{1}$ but the outer margin is not preserved. The inner margin certainly shows no sign of the presence of meristem.

Lepidodendron fuliginosum. Weiss assumed that the secondary cortical tissue was all phelloderm. ${ }^{2}$ Seward states that it is chiefly so. ${ }^{3}$

Lepidodendron Scottii.

Bothrodendron mundum.

Sigillaria tesselata.

Sigillaria spimulosa. In an allied species Renault and Roche speak of the internal renewal of the periderm layer. ${ }^{4}$ The material available for the present paper did not show either margin of the secondary cortical tissue, but it will be shown later (p. 307) that it is more probable that the phellogen was on the outer side.

In an examination into the physiological anatomy of the periderm, this question as to the position of the phellogen in the tissue would seem to be of the greatest importance. It may therefore be stated at once that, whatever the morphological nature of the secondary tissue, there is no evidence to show that any of it was other than secondary cortex, even when some portion is formed on the outer side of the phellogen. It is probable from the whole nature of the periderm and its formation that in the fossil Lycopodiales there was not that strict division of labour which so sharply differentiates the cork from the phelloderm in the periderm of gymnospermous and dicotyledonous plants. If this is so the direction of the divisions (i. e. centripetal or centrifugal) is no longer connected with difference in function, and becomes a matter of minor significance.

\section{(5) Persistence.}

In the species examined the original phellogen was persistent, at least up to the time of preservation, and was not, as in so many recent plants, replaced at intervals by the development of a more internal phellogen. ${ }^{5}$ Arber and Thomas have suggested that it was of a periodic nature, at any rate in Sigillaria scutellata, on account of the difficulty in distinguishing a definite cambial layer, and of the presence of concentric zones in the periderm, which they interpreted as rings of growth. ${ }^{6}$ When it is remembered, however, what a very large number of specimens show no definite phellogen, and that only a few of these are at all regularly zoned, it

1 Seward and Hill (29), p. 9 I 7 .

${ }^{3}$ Seward (28), p. I53.

5 With one possible exception (see p. 317 ).
${ }^{2}$ Weiss (33), p. 229.

4 Renault and Roche (23), p. I7.

${ }^{6}$ Arber and Thomas (1), p. 14 I. 
seems more likely that this condition is due to the vicissitudes incidental to petrifaction, rather than to preservation at a time of inactivity of the meristem.

\section{The Periderm.}

\section{(I) General Description.}

The periderm forms a most striking feature of the stems and Stigmariae of fossil Lycopods. It may attain a thickness of seven or eight centimetres, and, in petrifactions of many specimens, periderm and xylem alone are preserved, while detached pieces of the tissue are also extremely common. Always easily recognizable, even in young specimens, by the character of its elongated cells and their arrangement in regular radial files, it may readily be distinguished near the periphery of the organ, where it forms a cylindrical or wavy band of tissue, often rather dark in colour, and very frequently showing some sort of zonation.

Generally the periderm presents a homogeneous appearance in transverse section, but, as has been mentioned, the outer layers of certain Stigmariae are very conspicuously extended tangentially, while in Sigillaria spimulosa and other species of its type the outer portion forms a network, of which the strands consist of typical periderm cells, while the meshes are filled with thin-walled parenchymatous tissue.

\section{(2) Size and Shape of the Cells.}

The characteristic cells of the periderm, which have frequently been described, are prosenchymatous, often many times as long as broad, with parallel sides and pointed, somewhat gabled, ends.

In transverse section they are generally smaller than the cells of the outer cortex, and vary considerably, both in size and shape, even in adjacent files (see Text-fig. 7, \&c.). On the whole they are radially elongated, except the outer cells near the phellogen, which are frequently tangentially extended. In the second type of Stigmarian periderm mentioned on p. 294, the tangential extension of many of the cells of the outer part of the tissue is most striking ( $\mathrm{Pl}$. XXIV, Fig. 2). It is not merely 'a necessary result of the position of the phellogen on the internal edge of the tissue and of the increasing girth of the axis', ${ }^{1}$ but depends on the actual nature of the widecelled portion, of which there are so few files compared to the number formed on the inner side of the supposed phellogen. In type I the extension is hardly noticeable (Pl. XXIV, Fig. I).

In radial section the appearance of the periderm is very characteristic on account of the parallel sides of the cells, and of all the members of one file being of uniform length, so that the end walls form almost straight lines. The variations in appearance produced, owing to most sections being more

\footnotetext{
1 Seward (28), p. 243.
} 
or less oblique, may readily be understood by means of cutting small models. Thus sections, without departing far from the radial, may cross from one file into another with end walls at a different level, or, if somewhat transverse, may cut across the side instead of the end walls, making the cells appear comparatively short (see Text-fig. I6, c).

In tangential section the periderm cells, as already stated, are commonly narrower, and their ends more pointed than in radial view (see Text-fig. I7). It is from tangential sections that the heterogeneous nature of the cells in certain periderms, which will be referred to later (p. 304), becomes at once apparent.

\section{(3) Character of the Radial Files.}

The cells of one radial file generally alternate with the contiguous cells of the files on either side, and frequently also with those above and

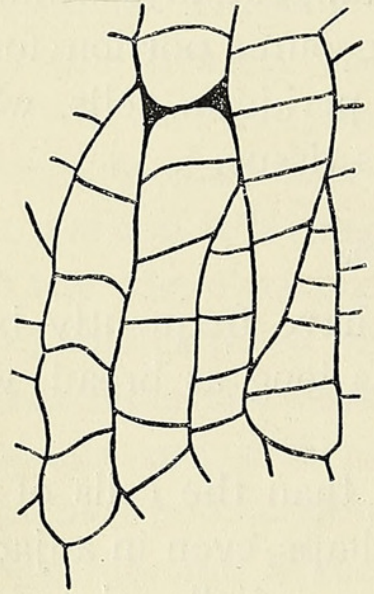

A

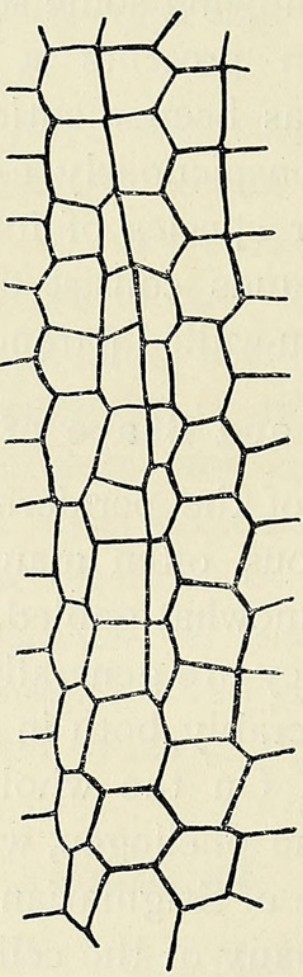

B

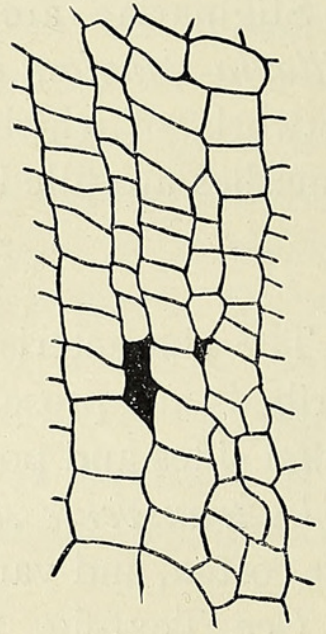

$\mathrm{C}$

Text-FIG. 10. Diagrammatic transverse sections showing short files in the periderm. A, Lepidodendron Hickii. Will. Coll., 380 b. B, Sigillaria scutellata. U. C. L. Coll., B I 2. C, Lepidodendron selaginoides. U.C. L. Coll., A or2. $\times 26_{5}$.

below. Haberlandt showed that in cork the former arrangement facilitated stretching in the tangential direction, ${ }^{1}$ while according to the same authority great additional strength is given to prosenchymatous tissues by the close interlacing of their pointed ends. ${ }^{2}$

Typically in transverse section each radial file extends throughout the width of the periderm, but most preparations show frequent exceptions

\footnotetext{
' Haberlandt (13), p. I27, $4^{\text {th }}$ ed. 
(see Text-figs. Io and II, A ; Pl. XXIV, Figs. I and 2, \&c.). Often there are files which do not quite reach to the outer border of the secondary tissue; then there are some files which taper away before reaching the inner margin, and, in a few species, also some which at neither extremity reach the border of the periderm. ${ }^{1}$ In Stigmariae the arrangement is specially irregular. The appearances produced are probably due to various causes. The files may not all run continuously in the same horizontal plane; or if the sections are not quite transverse, new files get cut across at intervals, first at the narrow ends of the cells, and then in the wider parts, while correspondingly other files gradually pass out of the section (Textfig. IO, B). Then again the periderm may not have originated in a single layer of cells at the same level (Text-fig. IO, A, and Text-

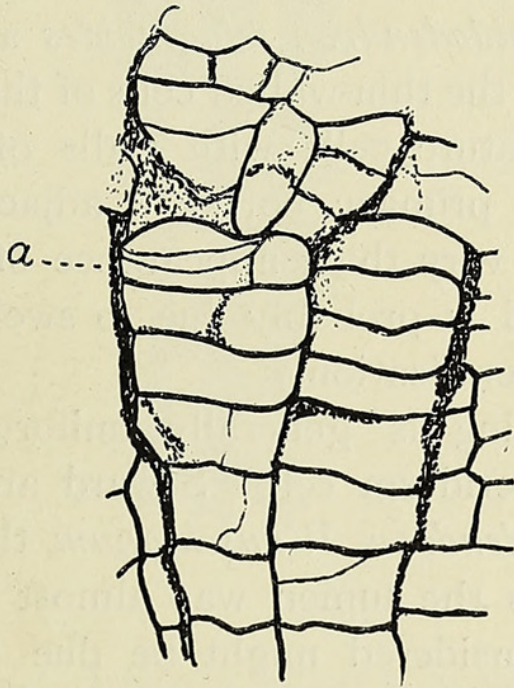

A

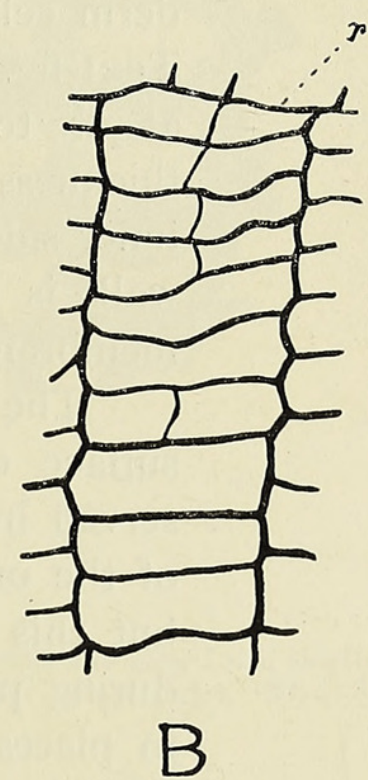

Text-FIG. II. Transverse sections from the outer part of the periderm of Stigmaria (type 2 ! A, irregular tangential divisions at $a$. B, recently formed radial septa forming a new short file, $r$. U. C. L. Coll., CC 7 h. $\times 90$.

fig. 4) ; and further irregularity is caused by radial divisions in the phellogen to keep pace with growth (see Text-fig. 5), and possibly also by displacement.

It appears probable that in some cases short files may be produced by subsequent division of the cells of the periderm (Text-fig. IO, C). This would help to account for the very irregular arrangement in Stigmariae (Pl. XXIV, Figs. I and 2), and recently formed radial septa may be traced in places (Text-fig. II, B). In the wide-celled type of Stigmarian periderm further tangential divisions may also take place (Text-fig. I I, A), as was mentioned on p. 294, and many of the cells of the cortex outside the periderm may start to divide (Pl. XXIV, Fig. 2,e), producing additional files, and

1 Similar short files may be found in transverse sections of the secondary wood of these plants. 
thus contributing to the irregular appearance. Sometimes almost the whole of the outer tissues appears to be in a meristematic condition.

\section{(4) Structure and Thickening of the Cell-wall.}

The outer primary cortex in the fossil Lycopodiales is typically thickwalled, and, in the species examined, the walls of the periderm cells are found to be of about the same thickness ${ }^{1}$ (Text-fig. 8, \&c.), though in some

Sigillariae they are rather thicker, and in Stigmariae

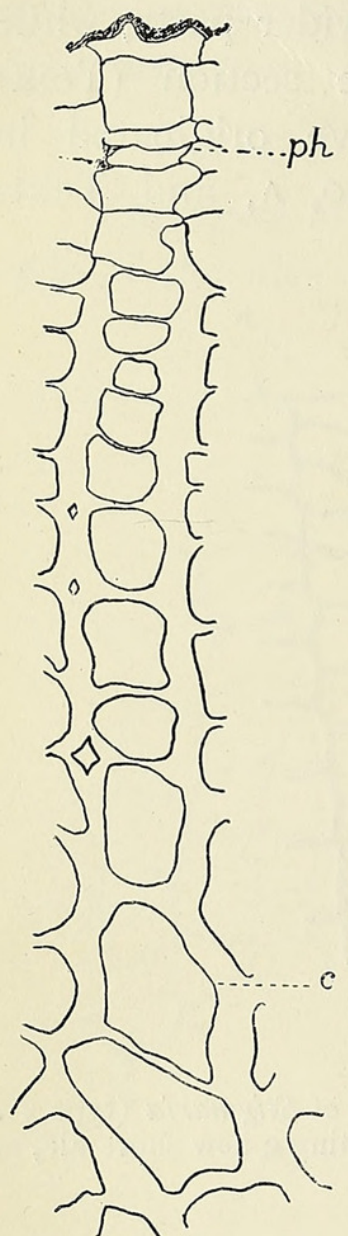

TEXT-FIG. I 2. Transverse section of a file of periderm cells of Lepidodendron selaginoides, showing the thickening of the walls. ph, phellogen; $c$, primary cortex. U.C.L. Coll., A or $2 . \quad \times 4$ Io. often considerably thinner. The frequent appearance of the periderm as a thickened band is generally due to the smaller size of the cells, sometimes also to brown coloration of the contents.

The stages in the thickening up of a file of periderm cells of Lepidodendron selaginoides are shown in Text-fig. I2, from the thin-walled cells of the phellogen at $p h$, to the mature cells with walls of the same thickness as the primary cortex $c$ adjacent on the inner side. (The very thick appearance of the radial walls is local, and is probably due to swelling of the membrane in mineralization.)

The thickening is generally uniform over the surface of the periderm cell. Seward and Hill observed in Lepidodendron Wunschianum that in some of the outer cells the lumen was almost obliterated, but this they considered might be due to swelling during petrifaction. ${ }^{2}$ In some other species there is in places noticeable swelling of certain of the walls. This is shown in Text-fig. I3, A, in a Lepidophloios, where it occurs on the radial walls, while in certain specimens of Lepidodendron selaginoides (Text-fig. I3, B) the outer tangential walls have the same appearance. This thickening is quite irregular in occurrence, and seems due to local swelling of the membranes, and possibly splitting of the middle lamella and subsequent filling with intercellular substance.

The walls of the periderm in general, as was noticed early, do not show any signs of pitting, not even of slit-like pits such as are found in the prosenchymatous tissues of recent plants. ${ }^{3}$ Renault stated that the periderm of Stigmaria Brardi consisted of reticulated cells, ${ }^{4}$ but these have since been referred to as if they were

1 The thin-walled cells of the meshes of Dictyoxylon types are not here considered.

2 Seward and Hill (29), p. 9I 7, Pl. IV, Fig. 27.

3 de Bary (11), p. I32, Haberlandt, \&c.

4 Renault (21), p. I95, P1. XXXIX. 
tracheides, ${ }^{1}$ while in a recent paper Zalessky speaks of the 'stries spiralées' seen in vertical sections of the periderm of his Lepidodendron obovatum. ${ }^{2}$

As regards the thickening substance, one can say with certainty that it was not suberin. The walls of the secondary cortex must have been permeable to water, for, whenever the tissues outside are preserved, they show none of the characteristic signs of arrested activity and collapse produced in cells isolated by a zone of cork. The impossibility of the periderm being of the nature of true cork has been pointed out several times, chiefly in regard to Stigmaria, ${ }^{3}$ though other writers who have recognized it as phelloderm have spoken of it as being cork-like in function, ${ }^{4}$ or as having

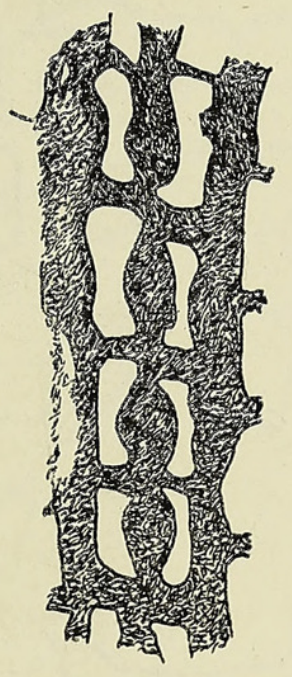

A

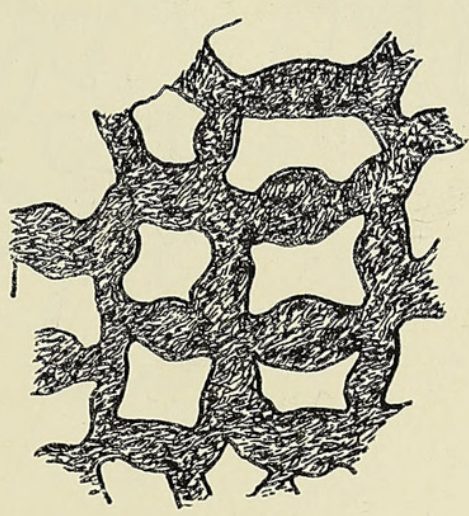

B

TEXT-FIG. 13. Transverse sections of certain periderm cells showing local swelling of the walls. A, Lepidophloios sp. U. C. L. Coll., A 32. B, Lepidodendron selaginoides. U.C.L. Coll., A oI 21. $\times 265$.

some suberized layers. ${ }^{5}$ It should perhaps be mentioned that the cork crusts of some recent plants do not always have suberized walls, e.g. Ulmus suberosa, but the quantity produced makes up for defects in quality, and many of the cells are true cork. ${ }^{6}$ In the plants under consideration the cortex nature of the periderm is confirmed by other qualities, and, though it may have contributed to the protection of the interior tissues, this was probably quite a secondary function. ${ }^{7}$

\section{(5) Cell Contents.}

The cells of the periderm of nearly all the species show as much sign of contents as the adjacent cortex, and there are therefore no indications

1 Weiss (36), p. 223; Seward (28), p. 242.

3 By Williamson and Solms, and later by Scott and Seward.

4 Weiss (33), p. 229.

6 See Haberlandt (13), p. I 25, $4^{\text {th }}$ ed.

7 Two cases of wound periderm in the fossil Lycopodiales have been mentioned, by Seward (27) and Weiss (34), but none has been examined in the present investigation. 
that the periderm was an empty, air-filled tissue, as is the cork of recent plants. Of course a very large number of the cells are empty, while others contain black lumps, such as may also be seen in the xylem, or are coloured brown in large patches. But cells with traces of apparently real contents are also found, some types of which are illustrated in Text-fig. I4. Of these the appearance of one cell of B may have been produced by the mycelium

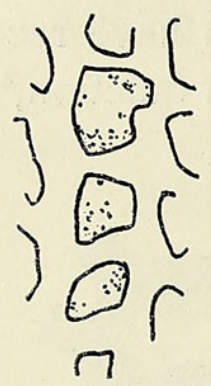

A

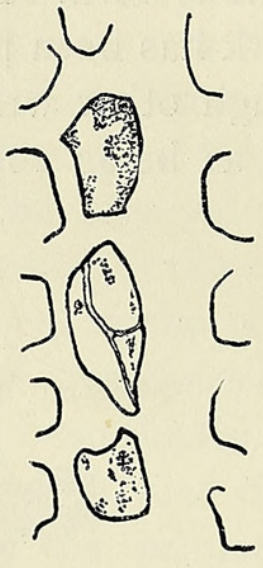

B

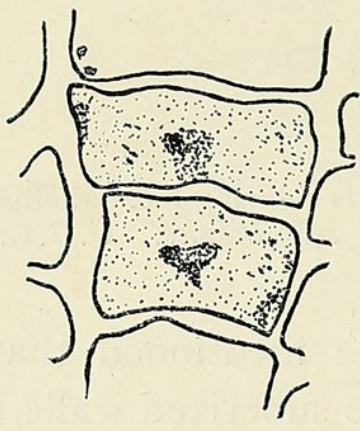

D

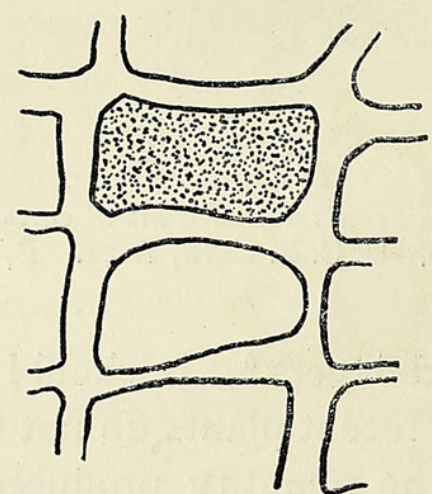

$E$

Text-FIG. I4. Types of the contents of periderm cells. A, Lepidodendron selaginoides. U. C. L. Coll., A or 22. B, Sigillaria scutellata. U.C. L. Coll., B II. C, Lepidodendron fuliginosum. U. C. L. Coll., A 32. D, Stigmaria. U.C. L. Coll., D 8. E, Lepidophloios sp. U.C.L. Coll., A 39 c. $\times 26_{5}$.

of a fungus. ${ }^{1}$ In E certain of the cells have an even brown stain, which may represent tannin or a like substance, while the contents of the periderm of Lepidodendron Wunschianum in tangential section have also been compared in appearance to vacuolated tannin. ${ }^{2}$ Tannin and its decomposition products may, however, be found also in true cork. ${ }^{3}$

\footnotetext{
${ }^{1}$ Cp. Lignier (16), p. 197, Fig. 4. ${ }^{2}$ Seward and Hill (29), p. 916 , Pl. III, Fig. 20. 
The contents are fairly evenly distributed through the tissue, and not, like the dried-up remains of contents in cork, in greater quantity near the phellogen.

\section{(6) Intercellular Spaces.}

As regards intercellular spaces, the periderm partakes of the nature of the outer cortex. This is on the whole a closely set tissue with but few intercellular spaces, and a certain number have been found in the periderm of all the species except Bothrodendron mundum and Sigillaria spinulosa.

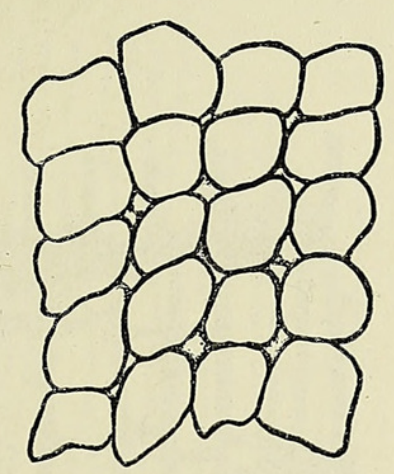

A.

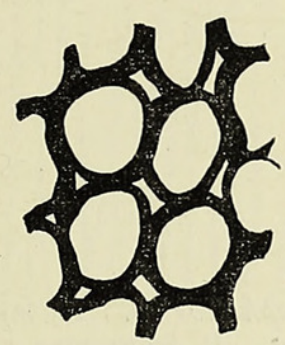

$\mathrm{C}$

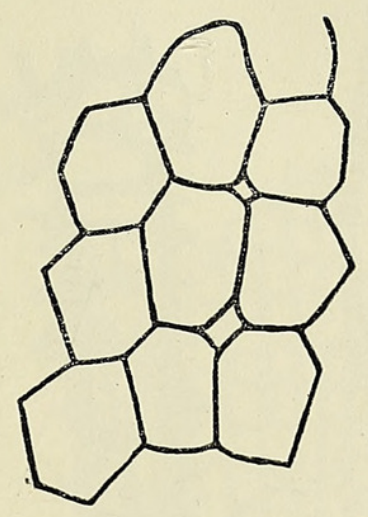

B

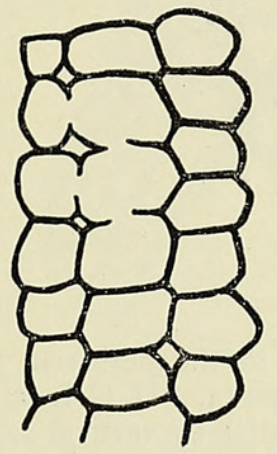

D

TEXT-FIG. I5. Intercellular spaces in the periderm. A, Lepidodendron selaginoides. U.C.L. Coll., A or 2. B, Stigmaria. U. C. L. Coll., D I. C, Lepidodendron Wunschianum. Will. Coll., 452. D, Lepidodendron Hickii. U. C. L. Coll., A I. E, Sigillaria sp. U. C. L. Coll., S37. $\times 265$.

Examples are shown in Text-fig. I5. In Lepidodendron Wunschianum the spaces are rather abundant, and attention was drawn to them by Seward and Hill. ${ }^{1}$

It would therefore appear that the periderm was at any rate as permeable to gases as the adjacent cortex.

1 Seward and Hill (29), p. 9 r5, Pl. III, Fig. 18. 


\section{(7) Heterogeneous Periderms.}

Bearing in mind the general nature of the periderm cells as described, one may now turn to the species in which the secondary cortical tissue is not quite homogeneous.

(a) The simplest variation from the ordinary type consists in the occurrence in the periderm of many cells which have become chambered by horizontal, and occasionally also by vertical septa ${ }^{1}$ (Text-fig. I6). These

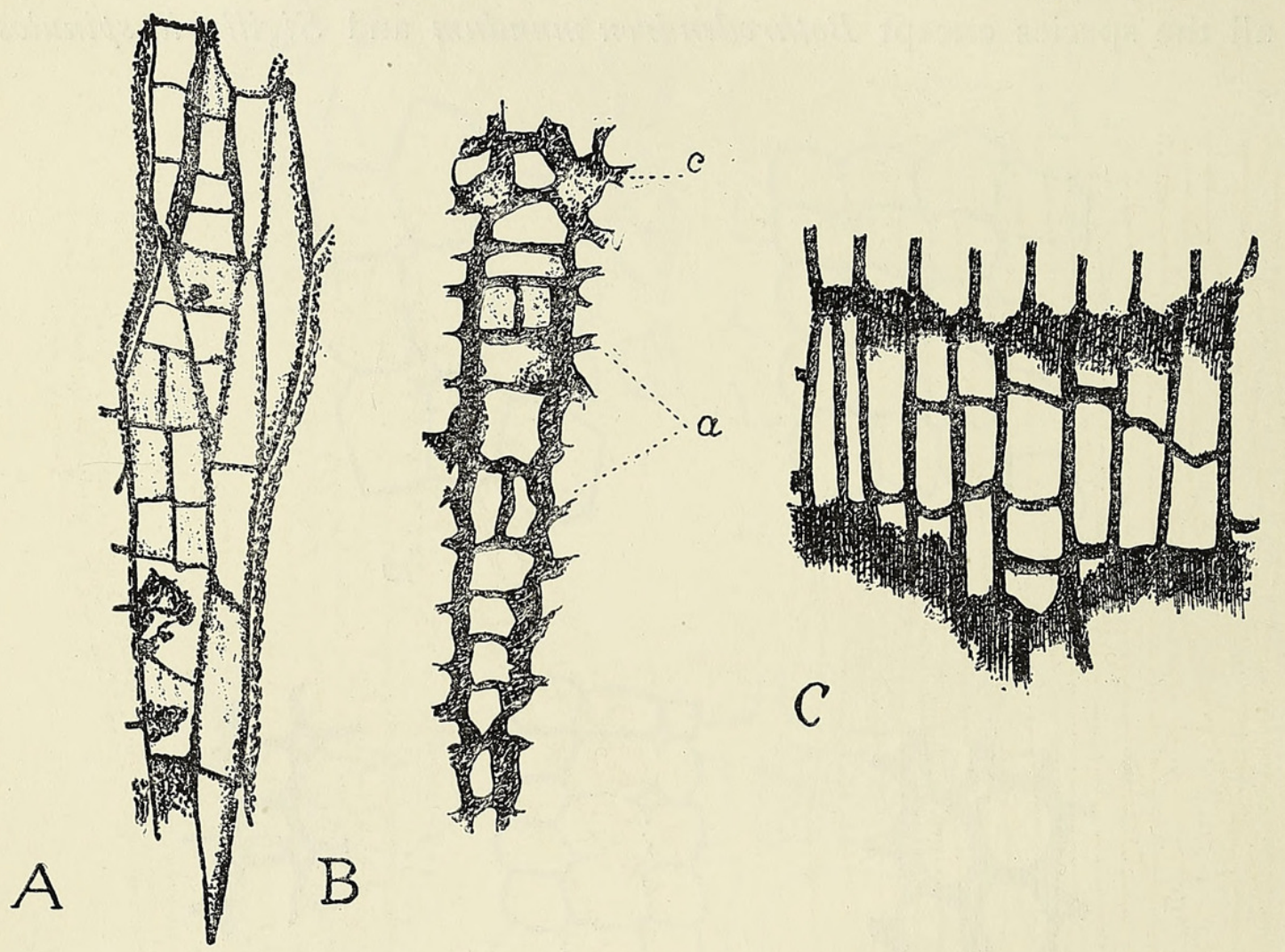

TeXT-FIG. I6. Chambered cells in the periderm of a Lepidophloios sp. A, tangential section showing both horizontal and vertical septa. U.C. L. Coll., A 39 g. B, transverse section near the outside of the periderm. $a$, cells divided by vertical septa; $c$, outer cortex. U. C. L. Coll., A 39 a. C, obliquely radial section from the outer border of the periderm. U. C. L. Coll., A 39 d. $\times 90$.

have been found in a species of Lepidophloios and also in a Lepidodendron. Of the former there are transverse (Text-fig. I6, B) and obliquely radial (Text-fig. I6, C) as well as tangential sections, from which it is seen that the chambered cells occur chiefly in the outer layers of the periderm.

(b) In the second case, as found in two forms of ribbed Sigillaria, one of which is referred to $S$. reniformis, there are the same chambered cells to be seen in tangential section, but they are arranged in definite vertical groups (Text-fig. I7), and are rather wider and lighter in colour than the rest of the periderm. The septa here seem to be all horizontal.

1 The cells recall somewhat the chambered bast and libriform cells of recent plants, but the transverse walls are not specially thin. 
In Sigillaria scutellata it has been noted that some of the cells, especially in the deeper portions of the phelloderm, are chambered, ${ }^{1}$ but no vertical sections of this species have been examined in the present investigation.

(c) It would appear that the complex periderm known as 'Dictyoxylon cortex' may be regarded as derived on similar lines to the above types. Dictyoxylon cortex, as often described, consists essentially of a network,

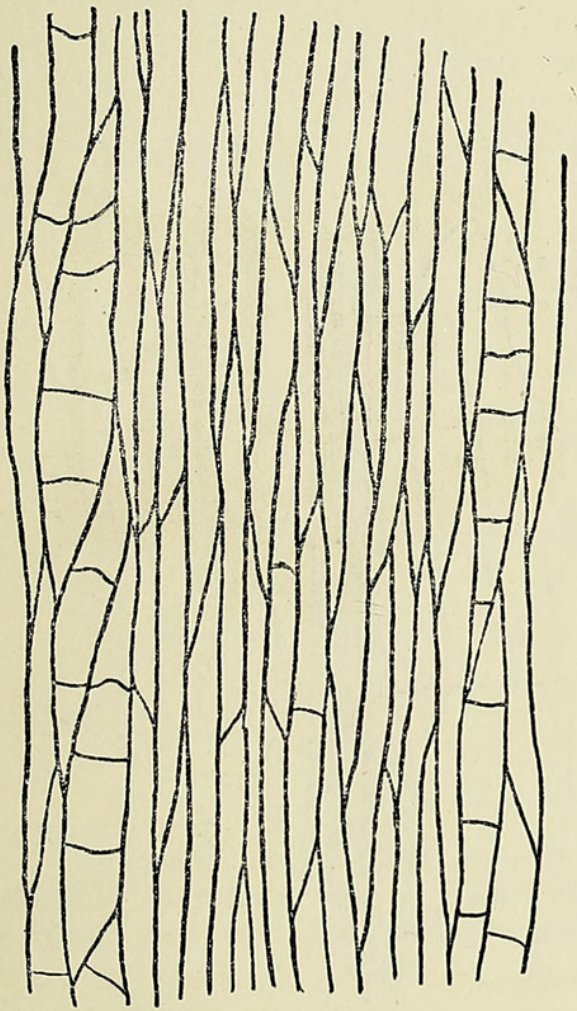

TEXT-FIG. I 7. Tangential section in the periderm of Sigillaria sp., showing vertical groups of chambered cells. Will. Coll., 662 . $\times 100$.

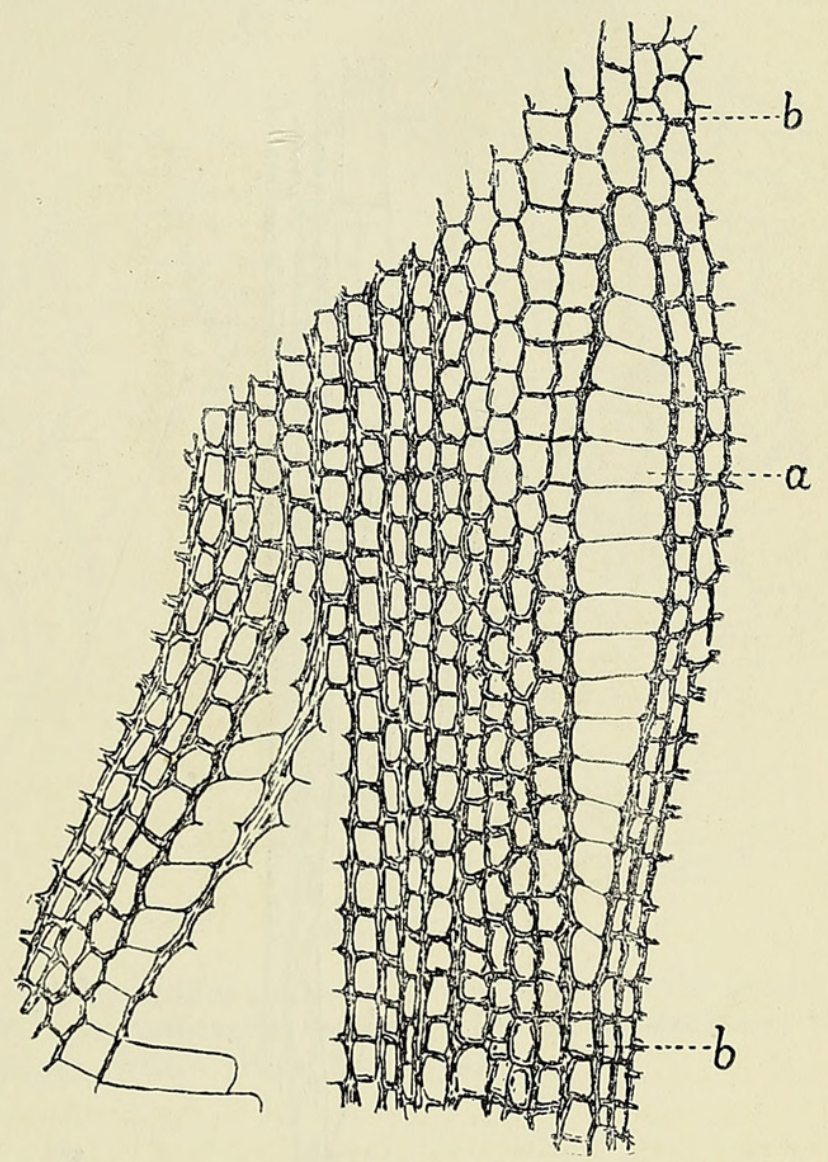

Text-FIg. I8. Sigillaria spimulosa. Transverse section in the periderm showing the origin of the thinwalled meshes, $a$, in the cells of the regular radial files, $b$. Will. Coll., $6_{5} . \quad \times$ Ioo.

of which the strands are ordinary periderm cells, while the meshes, visible alike in transverse and vertical sections, are filled with thin-walled, bricklike parenchyma. ${ }^{2}$ It is not to be confounded with the primary outer cortex of $L y$ ginodendron and Heterangium with its strands of fibrous sclerenchyma, to which the term 'Dictyoxylon' is also applied.

According to Renault, the meshes in Sigillaria spinulosa, \&c., are not found in the inner part of the tissue, and gradually increase in size towards the periphery. From the transverse section shown in Text-fig. I8, it will

1 Arber and Thomas (1), p. I42.

${ }^{2}$ Described in the following : Lepidodendron rhodumnense, Lepidodendron esnostense, Sigillaria spinulosa, Sigillaria lepidodendrifolia, Stigmaria Brardi. 
be seen that the delicate mesh cells, $a$, are formed in the ordinary radial files by a certain number of the cells being left thin-walled, and becoming extended in the tangential direction, whilst typical periderm cells, $b$, are present both within and without.

By examining the meshes in tangential section it is found that these thin-walled cells divide by horizontal septa into chambered cells, while each segment may undergo further vertical divisions (Text-fig. I9, A), so that later the outline of the original extended prosenchymatous cell is lost ; but
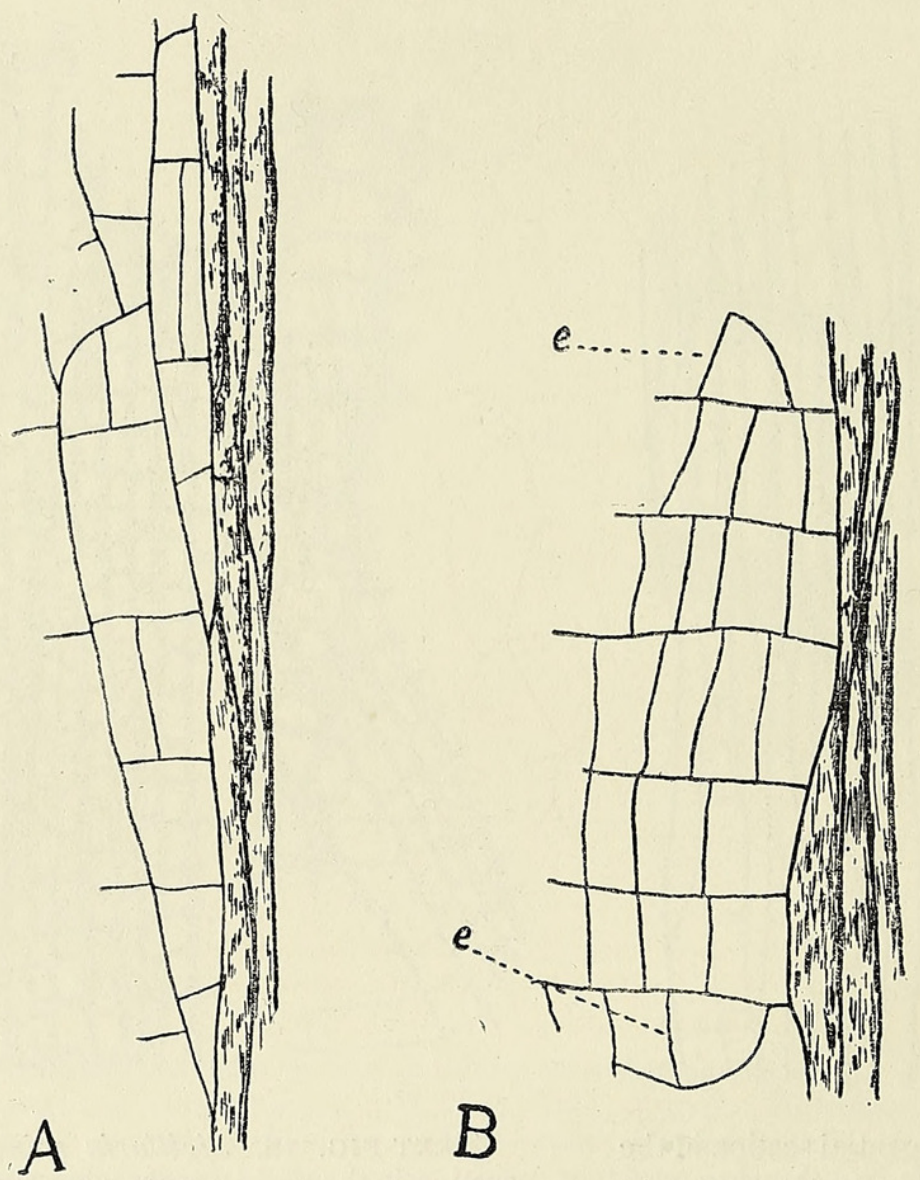

TEXT-FIG. I9. Sigillaria spinulosa. Tangential sections through two meshes, A and B. A still shows the extended thin-walled prosenchymatous cells of the mesh. In $\mathrm{B}$ the prosenchymatous form has been lost as a result of further divisions, but the pointed end-segments can still be seen at $e_{\text {. Will. Coll., } 668 . \times 100 .}$

the occurrence of the pointed end-segments still gives the clue to the origin of the mesh (Text-fig. I $9, \mathrm{~B}, e$ ).

As there are no thin-walled meshes left in the inner portion of the tissue, and as they increase in size towards the exterior, it would seem probable that the smallest meshes were the first formed, and that larger groups of cells were left thin-walled as time went on, i.e. that the phellogen was near the outer margin.

The Dictyoxylon arrangement perhaps presented a means of economy of thickening material and adaptation to a continually increasing circum- 
ference in a tissue which attained a great thickness $(7$ or $8 \mathrm{~cm}$.), and the growth of which may have been very rapid.

(d) Turning to the irregular wide-celled forms of Stigmarian periderm, it is found from tangential sections that here also a large number of the wide outer cells are chambered. ${ }^{1}$ Text-fig. 20, A, is drawn from a tangential section of the specimen figured in transverse section in Text-fig. $20, \mathrm{~B}$, and it is seen that many of the cells show subdivisions.
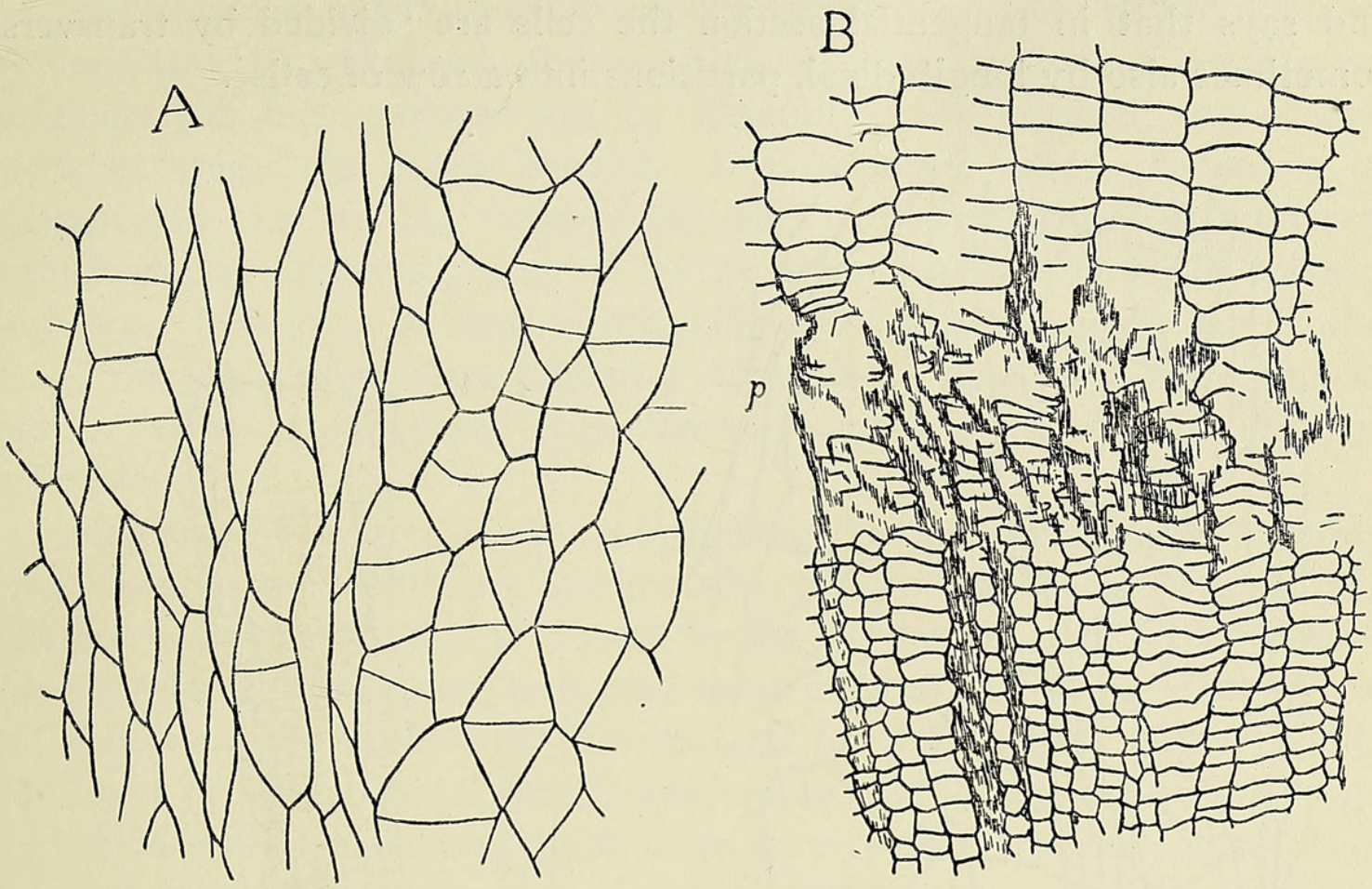

TeXt-FIG. 20. Stigmaria sp. (type 2). A, tangential section in the outer part of the periderm showing chambered cells. Will. Coll., 1785. B, transverse section of the same specimen; the probable position of the phellogen is shown at $p$. Will. Coll., I 780 . $\times 55$.

In other cases, where more narrow files intermix with the distended ones and the wide cells which become chambered occur in irregularly lenticular areas, a somewhat Dictyoxylon-like appearance is produced in tangential section (Text-fig. 21). As has been mentioned, Williamson described a series of sections of the above type, thinking they were identical with Renault's Sigillaria spinulosa. ${ }^{2}$ From this series, in which there is a large quantity of the regular inner portion of the periderm preserved, it is seen that the dividing cells occur in the outer wide-celled portion of the secondary tissue, and die out rapidly in the regular inner part.

It is probable that these Stigmariae should be referred to stems which have similar heterogeneous periderms. ${ }^{3}$

1 First noticed by Williamson (43), p. 20, Figs. 24 and 49.

2 Williamson (39), pp. 353-6, Pl. XXV.

3 As already found in Glathraria and Stigmaria Brardi, Renault (21), p. I94. 
(e) Mention may be made here of the presence in one section referred to, Lepidodendron brevifolium, of wedges of light-coloured cells, much extended tangentially, which start in the cortex on the outside of the periderm, and project some way into it. The cells are thin-walled and have often broken down; the rest of the periderm is badly preserved, and unfortunately no tangential sections are available. Part of one of these wedges is shown (restored) in Text-fig. 22. Zalessky ${ }^{1}$ mentions very similar wedges in the species he refers to Lepidodendron aculeatum, Sternb., and says that in tangential section the cells are 'divided by transverse, sometimes also by longitudinal, partitions into a row of cells'.

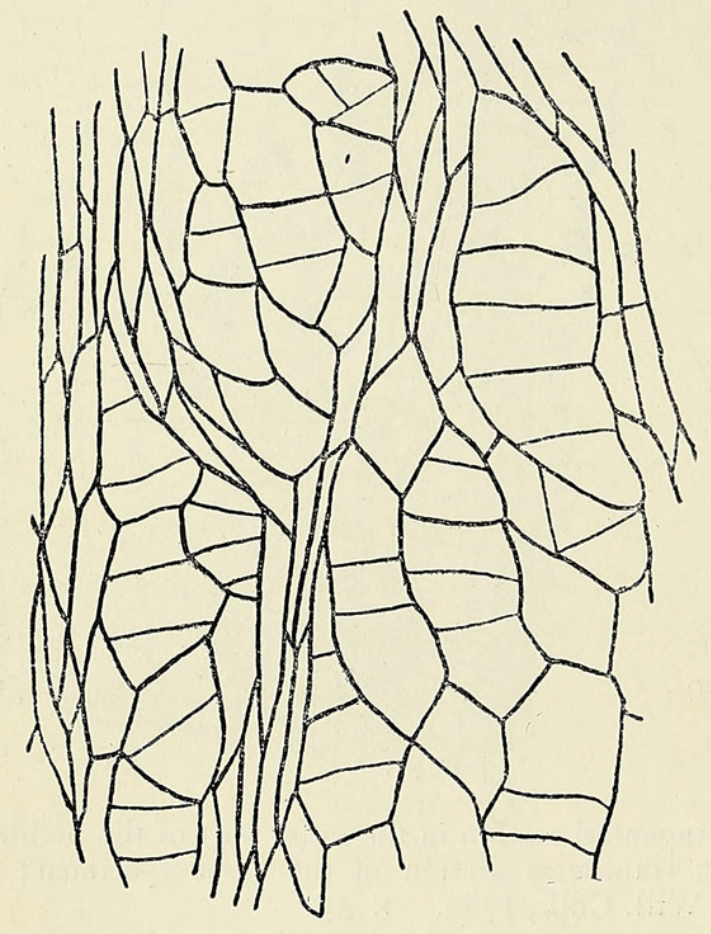

TEXT-Fig. 21. Stigmaria sp. (type 2). Tangential section in the periderm showing the wide chambered cells in lenticular groups. Will. Coll., 703. $\times 30$.

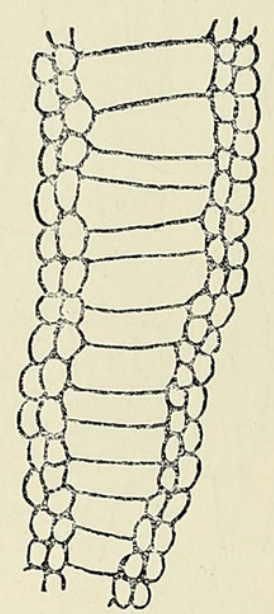

TEXT-FIG. 22. Lepidodenaron brevifolium. Diagrammatic restoration from a transverse section of a specimen which shows wedges of lighter-coloured extended cells on the outer border of the periderm. U. C. L. Coll., A 50. $\times 90$.

In all the types described, heterogeneous periderms therefore arise by the further subdivision of certain of the cells. Whether these cells occur in definite groups or not, and though there may be vertical as well as transverse divisions, the original form of the mother-cell is retained, except in Dictyoxylon types; in the latter the dividing cells have remained quite thin-walled and are capable of further growth, so that the original outline of the periderm cell is lost and the daughter-cells form a parenchymatous tissue, which becomes conspicuous in transverse as well as longitudinal sections. 


\section{(8) Features of Mechanical Significance.}

The cells of the periderm are generally well preserved and retain their clear outline, even in specimens which have been compressed quite out of their original form. They do not seem to have been easily extensible, and are inclined to break rather than stretch. The thin-walled periderms of Stigmariae seem the least resistant to pressure, while many of the species are specially crushable along certain lines.

The periderm of the stems in its structure and position is well adapted in every way to withstand physical strains, and its obvious mechanical usefulness has been pointed out by Renault, Scott, Seward, and others. 'Architecturally,' to quote Seward, 'Lepidodendron owed its power of resistance to the bending force of the wind to its stout outer bark formed of thick-walled elements produced by the activity of a cylinder of cortical meristem. The vascular axis, of insignificant diameter in proportion to the size of the stem, must have played a subordinate part, from a mechanical point of view, as compared with the solid mass of wood of a Pine or an Oak.' 1

Although often irregular in its beginnings, the periderm gradually forms a ring of more or less uniform thickness round the organ. Sometimes it is deflected outwards where it is crossed by the leaf-traces, as in Lepidodendron Harcourtii and fuliginosum, or it may be sinuous as in Sigillaria scutellata, \&c., following the outline of the ribs and furrows on the stem. By its position it probably contributed considerably to the support of the large number of evergreen leaves, which were very closely crowded, whether up the stem or at the extremities of the older branches. In Lepidodendron selaginoides a few extra layers of periderm are produced under each leafbase, while in dichotomizing branches, as noticed by Seward, ${ }^{2}$ there is often a stronger development of periderm in the fork. There also appears to be more periderm formed under the furrows of ribbed Sigillariae, but this has not been determined with certainty, as the periderm is broken off internally.

\section{(9) Zonation.}

Nearly all the species examined show some sort of zonation of the periderm. In Dictyoxylon types, for example, the zoned appearance is said to be due merely to the meshes being formed at more or less regular intervals. ${ }^{3}$ The zones are obviously of different kinds in various cases, and furnish another illustration of the difficulties of determining with certainty histological details in fossil-work.

One may conveniently distinguish:

(a) Colour zones. Here the whole periderm is divided into two or more bands, caused by differences in colour or in the preservation of the

\footnotetext{
1 Seward (28), p. 95.

${ }^{2}$ Loc. cit., p. I19, Fig. 152 .

${ }^{3}$ Renault (19), p. 252 .
} 
cells. Such zones have been found in specimens of Lepidodendron selaginoides, Hickii, brevifolium, Wunschianum, fuliginosum, Scottii and sp., Sigillaria elegans, scutellata, \&c. ; but, as their occurrence is not at all constant, it is possible that they are to be accounted for by events incidental to penetration and petrifaction of the tissues. Pl. XXIV, Fig. 3, shows these zones in Lepidodendron Scottii, where bands of black carbonized cells alternate with bands in which the structure is still preserved. ${ }^{1}$

(b) Zones caused by differences in size of the cells. In Sigillaria scutellata and allied species there are fairly continuous zones at rather irregular intervals, caused by a few layers of cells having their tangential walls closer together than the rest of the periderm (Pl. XXIV, Fig. 4). Arber and Thomas considered them definite rings of growth, supporting their suggestion that the phellogen was of a periodic nature. ${ }^{2}$ Of the zones described

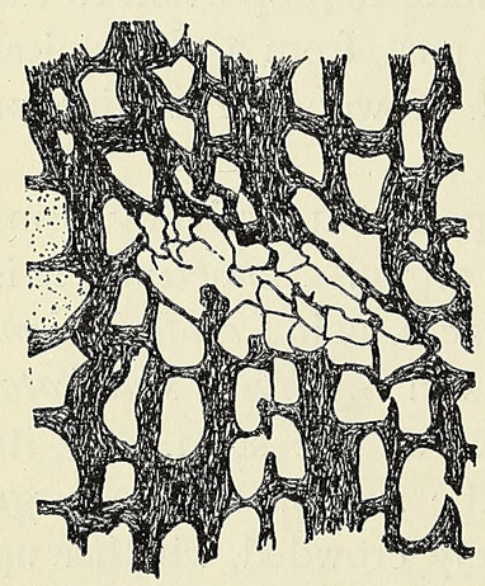

A

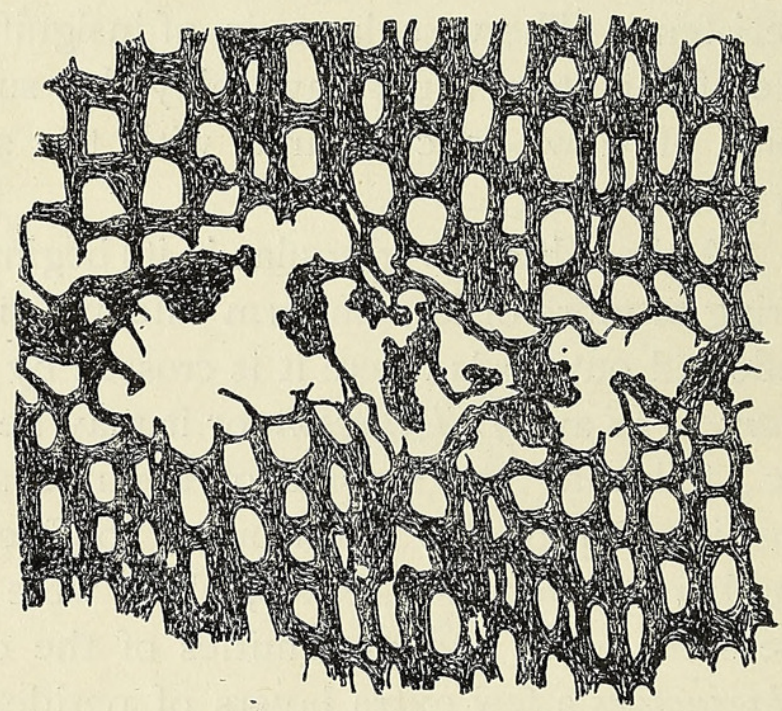

B

TEXT-FIG. 23. Lepidodendron selaginoides. Zones in the periderm. A, zone formed by thin. walled distorted cells. U.C.L. Coll., A 9. B, zone formed by breaking down of cell-walls. U. C. L. Coll., A or23. $\times 265$.

they seem to be the most likely to have been formed at periods of diminished activity. The secondary wood, however, shows no sign of seasonal change, but it is possible that the nearness of the phellogen to the surface would make it more susceptible than the cambium to slight, unfavourable alterations in atmospheric conditions.

(c) Zones formed by regular or irregular lines of cells which may be crushed or completely disorganized, or which may show signs of recent divisions. Under this heading have been grouped the various types of zones found in the periderm of Lepidodendron selaginoides, Wunschianum, Stigmariae, \&c. In Lepidodendron selaginoides they form irregularly concentric but not continuous lines, and consist of a few layers of cells, rather

\footnotetext{
1 Gordon (12) suggested that these zones were due to some sort of periodic rest.
}

8 Arber and Thomas (1), p. I 4 I。 
thin-walled and often crushed and distorted (Text-fig. 23 , A), or with the walls broken down so as to produce a series of holes (Text-fig. 23, B). Sometimes one or two of the cells show signs of tangential division. In many sections the zones appear merely as broken, narrow, black bands.

In Lepidodendron. Wunschianum the zones are much more continuous,

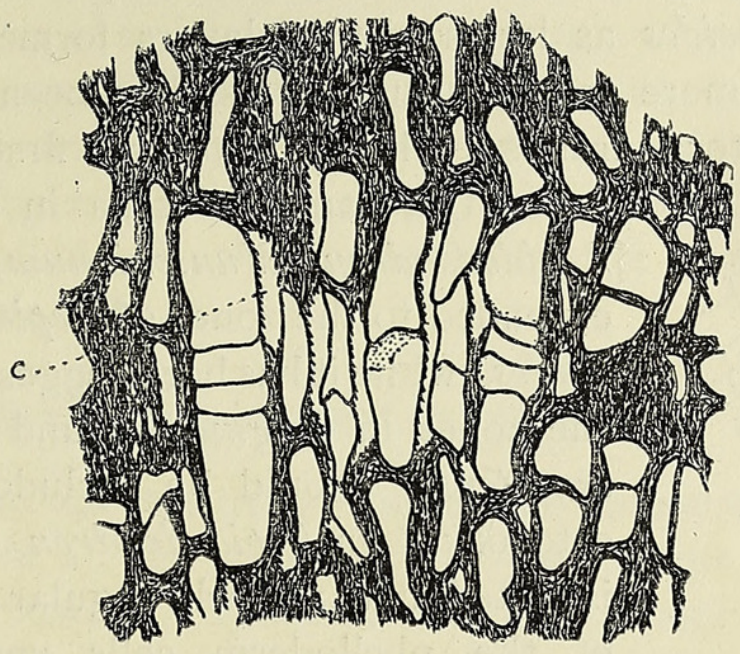

A

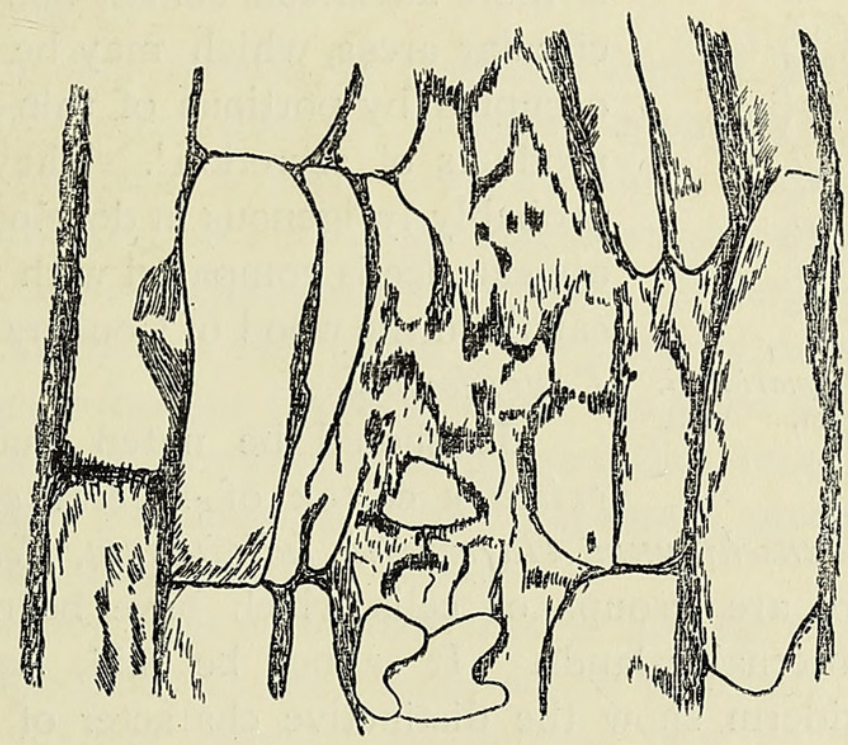

B

TeXT-FIG. 24. Lepidodendron Wunschianum. Zones in the periderm. A, transverse section. c, crack. Will. Coll., 452. B, radial section. Will. Coll., 446. $\times 265$.

and, owing to the lightness of colour of the cells and their thinner walls, they stand out as concentric white lines in the periderm. Many of the cells appear to have undergone recent division, and some are disorganized or, as is much of the periderm, masked by dark substance (Text-fig. 24). These 
zones may also be traced in vertical sections (Text-fig. 24, B); they have been described and figured by Seward and Hill. ${ }^{1}$

In Stigmariae the periderm is sometimes zoned by layers of very much crushed or broken-down cells (Text-fig. 25), and between these zones there are, in a few specimens, darker-coloured groups arranged more or less in rows.

As to the nature of all these zones, Hovelacque regarded them in Lepidodendron selaginoides as less resistant layers formed at periods of sluggish growth, ${ }^{2}$ but more recently much stress has been laid upon their interpretation as secretory strands. This function was first ascribed to the concentric bands of cells in the periderm of

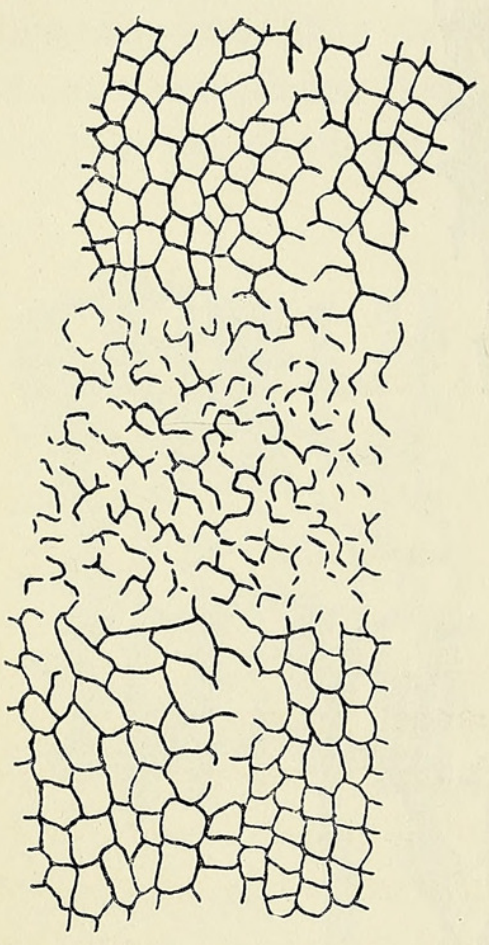
Zones in the periderm. Will. Coll., $766 . \times 55$.
TEXT-FIG. 25. Stigmaria sp.

Lepidodendron Wunschiamum, ${ }^{3}$ and was then extended to the zones of Lepidodendron selaginoides, ${ }^{4}$ while it has been suggested that possibly the zones in Stigmaria ${ }^{5}$ and Syringodendron esnostense ${ }^{6}$ should be included in the same category. In Lepidodendron Wunschianum it is stated that 'at fairly regular intervals groups of the phelloderm cells underwent further division, and constituted definite strands of secretory cells', which, when disorganization is more advanced, consist mainly of 'oval and circular areas, which may be either empty or occupied by portions of thin-walled cells and products of secretion'. They are said to be probably lysigenous in development, and their appearance is compared with that of the resincanals in the wood of Conifers and in Copaifera Langsdorffi. ${ }^{7}$

It should be noted that in the outer primary cortex of several species, including Lepidodendron Wunschianum, Harcourtii, fuliginosum, Bothrodendron, and Xenophyton, there are groups of cells which have been very generally interpreted as internal glands. It cannot be said, however, that the zones in the periderm show the distinctive character of secretory tissue. Although lysigenous glands in recent plants are surrounded by the remains of dissolved or obliterated cells, and not by an epithelium, yet their distinguishing feature is the formation of a passage, which starts in a single cell and proceeds in the centrifugal direction. ${ }^{8}$ But in the zones of these periderms cavities are by no means general, even in the old specimens which

1 Seward and Hill (29), p. 916, Figs. 2, 3, I2, I8, and 3 I.

2 Hovelacque (I 5 ), p. $5^{8}$.

4 Seward (28), pp. 118, I 2 I.

6 Seward and Hill (29), p. 925.

8 Tschirch (31), p. 508 .
3 Seward and Hill (29).

5 Seward (28), p. 244.

7 Seward and Hill (29), p. 9r6. 
one may reasonably suppose to have reached full development, while dark substance seems too widely distributed over the sections to give reliable evidence of secreted material. The presence of cells showing signs of recent division is also unusual in secretory tissue, except in quite immature schizogenous glands. ${ }^{1}$

The appearance produced seems on the whole such as might be caused by the formation at intervals of layers or groups of cells with rather thinner walls (sometimes capable of division), which have in consequence been more liable to crushing or to degeneration; somewhat as in the corks of many recent plants, where concentric zones, not always seasonal, are formed by the alternation of wide, thin-walled cells with layers of flatter cells with thicker walls, stone cells, \&c. ${ }^{2}$

\section{(10) Periderm Development in relation to other Tissues.}

The periderm appears early-before the secondary wood, where this is also developed-in all the species examined, except Lepidodendron brevifolium and intermedium, Sigillaria scutellata, tesselata, and spinulosa, and Stigmariae, in which evidence on this point was lacking. Only two sections, one of which is of Lepidodendron selaginoides, show some few layers of secondary wood before periderm formation has extended round the stem (see Text-figs. I and 2).

Correlation of the amount of periderm formed, and the amount of secondary wood developed, does not show any apparent connexion between the tissues. The periderm is nearly always as thick as the secondary wood, frequently much thicker, ${ }^{3}$ in all the specimens examined which were complete enough to allow of determination; but the periderm of Lepidodendron selaginoides, for example, is very much more strongly developed than that in a branch of Lepidodendron Hickii of about the same size, and which had no secondary wood. This serves to emphasize that these thick periderms had probably other functions than to compensate mechanically for the feeble development of the vascular system.

In this connexion it is noticeable that in all the fossil Lycopodiales there is a great deficiency of the tissues which generally serve for carbohydrate storage. There may be no definite pith, as in Lepidodendron selaginoides, or it is comparatively small, owing to the central concentration of the vascular axis. There is no wood parenchyma, except in the anomalous secondary zone of the type found in Lepidodendron fuliginosum. The medullary rays, which are all secondary, are generally very narrow and often contain tracheides.

\footnotetext{
1 In this connexion it might be mentioned that the 'glands' in the primary cortex of Lepidodendron fuliginosum consist almost entirely of delicate meristematic cells.

2 de Bary (11), pp. II 3-I 4, \&c.

${ }^{3}$ As in Lepidodendron selaginoides, L. Wunschianum, Sigillaria scutellata, \&c.
} 
Lepidodendron selaginoides is particularly lacking in these tissues, but its periderm is far more conspicuously developed than in Lepidodendron Hickii or L. fuliginosum. It is conceivable that the large secondary cortex took the place of the defective storage tissue, and that this might account for its striking development in these plants. Such a function would also be consonant with the formation of the great quantity of thin-walled periderm found in the underground Stigmarian rhizomes, where, from their nature and position, the mechanical function must have been of secondary significance. It is also possible that the storage of food reserves was more specially the part of the strongly developed, regular, interior portion of the periderm of certain types, while the less crushable, outer, wide-celled layers had a more mechanical and protective part, and in this connexion were aided by the meristematic properties of the cells of the outer cortex, in the event of rubbing off at the surface, or other vicissitudes to which rhizomes in the soil may be subject.

\section{The External Manifestations of Periderm Development.}

\section{(I) The Tissues outside the Periderm.}

As the periderm was not of the nature of cork, the tissues outside it do not dry up, but remain unchanged by its formation. This may be well seen by comparing a young Lepidodendroid stem without periderm with one in which it has attained considerable development. The cells of the leaf-bases and outermost primary cortex present the same appearance in both cases, and occasional divisions continue to take place. In some Stigmariae it has been seen (p. 294) that such divisions are very frequent.

The tissues outside the periderm do not show much sign of tangential stretching, except sometimes in the angles between adjacent leaf-bases, and must be able to keep pace with the growth of the circumference. Among the intact specimens examined, the leaf-bases are still persistent with the following developments of periderm:

Lepidodendron selaginoides

$\begin{array}{cl} & \text { Harcourtii } \\ & \text { Hickii } \\ & \text { Wunschianum } \\ & \text { brevifolium } \\ & \text { obovatum } \\ & \text { fuliginosum } \\ " & \text { Scottii } \\ \text { Sigillaria scutellata } & \text { sp. (Lepidophloios) } \\ " & \text { elegans } \\ " & \text { sp. }\end{array}$

about 200 rows of periderm cells.

$\begin{array}{lrll}" & 120 & " & " \\ " & 20 & " & " \\ " & 20 & " & " \\ " & 30 & " & " \\ " & 50 & " & " \\ " & 35 & " & " \\ " & 60 & , & " \\ " & 50 & " & " \\ " & 120 & , & , \\ " & 80 & , & , \\ " & 50 & , & ,\end{array}$


In Bothrodendron, Stigmaria type I, and Stigmaria type 2 the outer primary cortex is persistent with a development of 10,40 , and 80 rows of periderm cells, respectively.

The lack of cork and the nearness to the surface of a delicate layer like the phellogen may be mentioned as lending support to Seward's suggestion, owing to the absence of annual rings in the wood, that these plants were not exposed to seasonal change but grew under uniform climatic conditions $;^{1}$ nor could the conditions have been extreme in character.

\section{(2) The Outside Sculpture.}

It has been seen above that there is no evidence in the fossil Lycopods of the presence of bark, in the sense of dead and dried-up tissues which have been cut off by the production of a zone of cork ; but the question still remains whether the leaf-bases, and subsequently the outer layers of the periderm, were thrown off during life as the natural sequence of increase in age and girth of the organ. This has been taken as the normal course of events by many writers. Among others, Hovelacque stated that in Lepidodendron selaginoides decortication would take place along the zones in the periderm, ${ }^{2}$ and Renault along the zones between the meshes in the Dictyoxylon types, ${ }^{3}$ while Williamson spoke of the outer tissues being thrown off in Lepidodendron Wunschianum, though not during life in Stigmaria. ${ }^{4}$ More recently, Seward has described the stretching and gradual obliteration of the leaf-cushions, the production of longitudinal fissures, and later the exfoliation of the outer tissues both in Lepidodendron and Sigillaria, ${ }^{5}$ so that in Lepidodendron Wunschianum, for instance, 'the bark presents a fissured appearance like that with which we are familiar on an old Oak or Elm stem.' ${ }^{6}$ On the other hand, Potonié commented on there being no formation of bark, as the epidermis is retained and follows the growth in thickness of the stem. ${ }^{7}$

In considering this question it must be remembered that specimens are found showing every stage of decortication with the corresponding differences in external appearance, which originally led to the foundation of the false genera, Bergeria, Aspidiaria, Knorria, \&c. The difficulty is to determine how far these specimens represent the condition of the plant during life. Stems with furrowed outer layers have certainly been found, ${ }^{8}$ while the great prevalence of detached pieces of periderm, or of periderm and the tissues outside, might be adduced as pointing to some of these having been cast off during life.

1 Seward (28), p. 269.

2 Hovelacque (15), p. I 58.

8 Renault (21), p. I76; Renault and Roche (23), p. 8.

* Williamson (40), p. 497 ; (43), p. 26.

6 Seward (28), pp. 94, 105, I I 8, \& c.

6 Loc. cit., p. I 70.

8 Described by Binney, Dawson, Williamson, Seward, \&c.

Potonié (18), pp. 2 I9, 249. 
As far as the present investigation goes, none of the petrifactions examined show any sign of longitudinal fissures, except one obviously much mutilated specimen of Lepidodendron brevifolium. The oldest example of Lepidodendron selaginoides has a periderm two inches thick, which is divided into wedges, as is usual in this species, but the wedges taper inwards towards the centre of the stem; while there are specimens of Lepidodendron Wunschianum and of Stigmariae with still thicker periderm and no sign of furrows. Again, impressions of great size are found with the

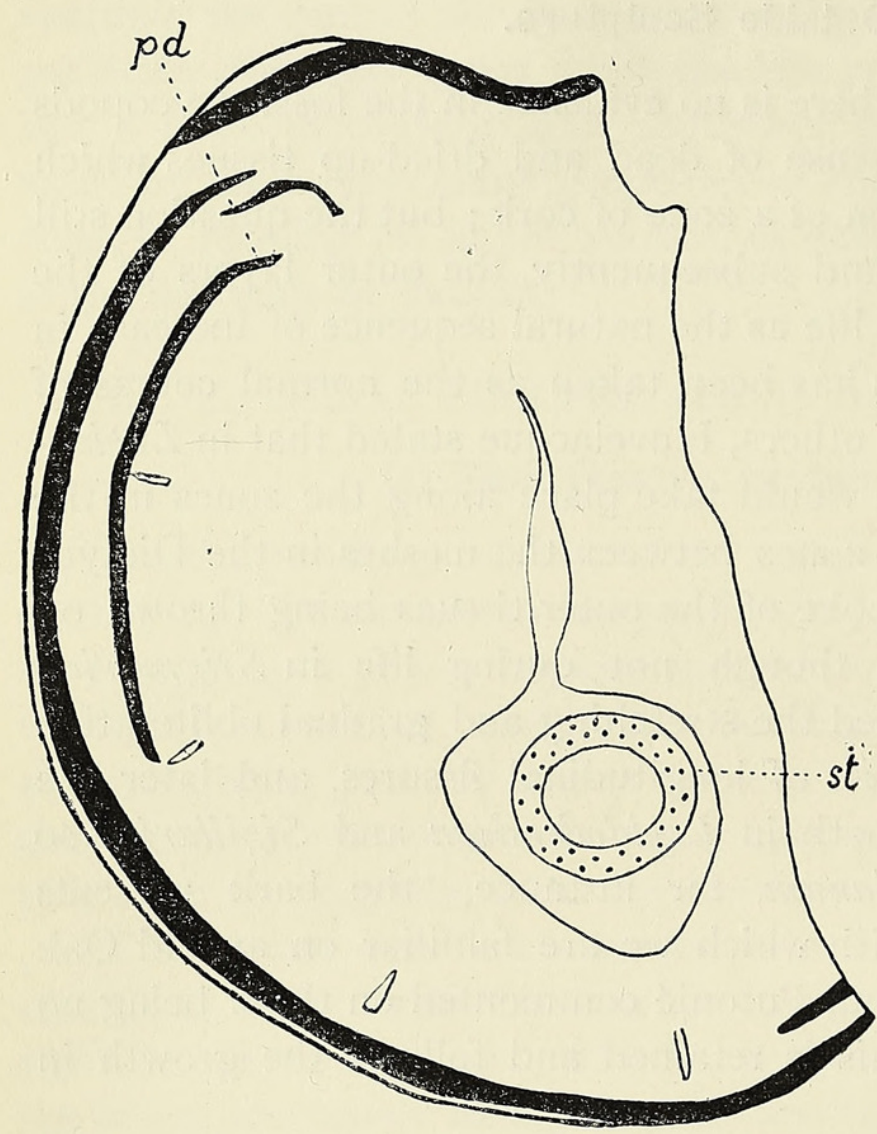

Text-FIG. 26. Lepidodendron fuliginosum. Diagrammatic transverse section of a specimen showing several narrow bands of periderm. The periderm, $p d$, is shown in black; st, stele. Will. Coll., $38_{5} . \times 2$.

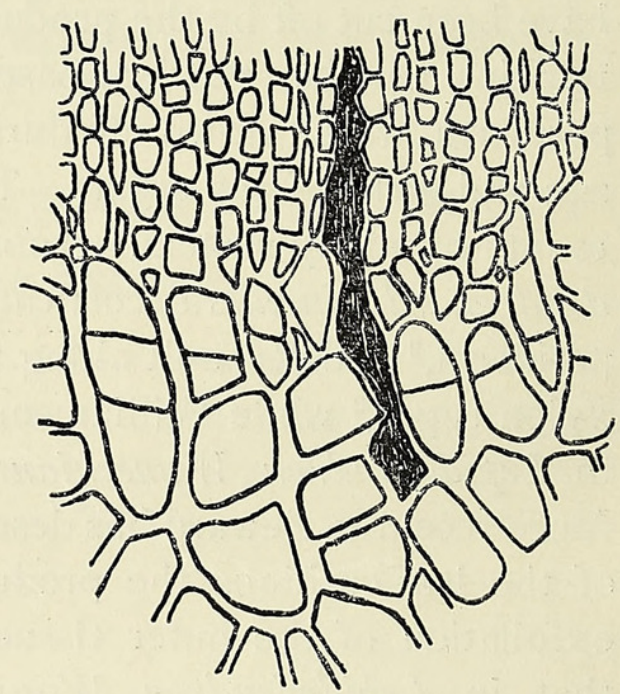

TEXT-FIG. 27. Lepidodendronfuliginosum. Transverse section in the periderm showing layers added by division of the cells on the inner margin. U. C.L. Coll., A $32 . \times 90$.

leaf-bases still intact and showing no fissuring or distortion, as, for example, a specimen attributed to L. aculeatum in the Natural History Museum, with leaf-cushions over two inches long.

There is another difficulty with regard to the exfoliation theory which was touched on by Williamson in his monograph on Stigmaria. ${ }^{1}$ In Lepidodendron selaginoides (vasculare), for instance, Hovelacque considered the periderm as true cork, but it is now generally recognized that the bulk of the secondary cortical tissue is phelloderm. If ' at a later stage the cushions 
were thrown off, leaving the outer edge of the phelloderm as the superficial tissue ', ${ }^{1}$ the phellogen layer would disappear in the process, and it is not stated how further development of periderm, if any, continued. The production of a more internal phelloderm would be the obvious solution, but of this there is no mention in any of the old stems of the various species ${ }^{2}$ described as having a fissured bark. Nor has any evidence been obtained of the formation of a second periderm in these plants, except in one small and apparently abnormal specimen attributed to Lepidodendron fuliginosum (Text-fig. 26). Here periderm formation has started at four different levels. The bands are all narrow and discontinuous, and there is nothing to show that one is developed to replace the other. Scott has also mentioned the formation in places of a second periderm in Lepidodendron obovatum, ${ }^{3}$ while in one or two species (Lepidodendron selaginoides and fuliginosum) a few layers may be added to the periderm by division of the cortical cells on the inner margin, but these only form a string of four or five cells (Text-fig. 27).

In the massive corks of recent plants, when the stage of exfoliation has been reached, the cork layer is maintained at a uniform thickness by the internal renewal balancing loss by decortication, but there is no sign of this or any compensating arrangement in the periderm of the Lycopodiales should it also have been cast off during the life of the plant.

In the absence of any provision for the consequences of exfoliation, and also of any physiological reason for the formation of bark and later decortication in the development of a secondary cortex as opposed to cork, the evidence at present obtained may be held to support the remark of Scott that 'when the leaves were shed their bases remained attached to the stem, forming the leaf-cushions, which were persistent, even on the larger trunks'. ${ }^{4}$

\section{SUMmary.}

The periderm of the fossil Lycopod attained a great and conspicuous development.

It is of the nature of secondary cortex, and is, for the greater part, morphologically phelloderm.

The cells are prosenchymatous; in certain species some become subdivided into groups of smaller cells, the extreme development of this condition producing the type of tissue known as Dictyoxylon cortex.

Concentric zones may be present in the periderm, due to differences in the nature of certain layers of cells.

The periderm forms a complete and apparently continually increasing cylinder near the periphery of the organ, and seems to have served as the

1 Seward (28), p. I I 8.

2 Lepidodendron selaginoides, L. brevifolium, L. Wunschianum, Sigillaria.

3 Scott (25), p. 318 ; figured Seward (28), p. I 54 .

+ Scott (24), p. I 28. 
main supporting tissue of the stems, for which it was well qualified by its physical properties.

In addition to its mechanical function it is possible that it acted as reserve storage tissue, for which there is no adequate provision elsewhere than in the cortex.

The periderm, as far as has been ascertained, does not appear to have become the outermost tissue, and is not primarily a protective integument, as is the periderm of recent plants.

The above investigation was undertaken at the suggestion of Professor F. W. Oliver, and I should like to take this opportunity of expressing my thanks to him for all his help and advice, and to Mr. T. G. Hill, who has also given me much kind assistance.

\section{LITERATURE CITED.}

1. Arber, E. A. N., and Thomas, H. H. : On the Structure of Sigillaria scutellata, Brongn., and other Eusigillarian Stems, in comparison with those of other Palaeozoic Lycopods. Phil. Trans. Roy. Soc., vol. cc B, I908, p. I33.

2. mamillaris, Brengn. Ann. Bot., vol. xxiii, 1909 .

3. Bertrand, C. E. : Remarques sur le Lepidodendron Harcourtii de Witham. Trav. et Mém. Fac. Lille, vol. ii, Mém. 6, r 89 I.

4. Binney, E. W.: On some Plants showing Structure from the Lower Coal Measures of Lancashire. Quart. Journ. Geol. Soc., vol. xviii, 1862, p. 106.

5. - A Description of some Fossil Plants showing Structure, found in the Lower Coal Seams of Lancashire and Yorkshire. Phil. Trans. Roy. Soc., vol. clv, I865, p. 579.

6. : Observations on the Structure of Fossil Plants found in the Carboniferous Strata. Part iii, Lepidodendron. Palaeont. Soc. London, 1872.

7. $:$ Part iv, Sigillaria and Stigmaria. Ibid. 1875.

8. Brongniart, A.: Observations sur la structure intérieure du Sigillaria elegans. Arch. Mus. d'Hist. Nat., vol. i, I839, p. $4{ }^{\circ} 5$.

9. Dawes, J. S. : Remarks upon the Internal Structure of Halonia. Quart. Journ. Geol. Soc., vol. iv, I 848, p. 289.

10. Dawson, J. W.: On the Structure and Affinities of Sigillaria, Calamites, and Calamodendron. Quart. Journ. Geol. Soc., vol. xxvii, i87 I, p. 147.

11. DE BARY, A. : Comparative Anatomy of the Phanerogams and Ferns. Oxford, 1884.

12. Gordon, W. T.: On Lepidophloios Scottii, a new Species from the Calciferous Sandstone Series at Pettycur, Fife. Trans. Roy. Soc. Edin., vol. xlvi, 1908, p. 443.

13. Haberlandt, G.: Physiologische Pflanzenanatomie. Leipzig, 1896 . Fourth edition, 1909.

14. Hick, T. : On a new Fossil Plant from the Lower Coal Measures. Journ. Linn. Soc. Bot., vol. xxix, I893, p. 86.

15. Hovelacque, M.: Recherches sur le Lepidodendron selaginoides, Sternb. Mém. Soc. Linn. Normandie, vol. xvii, 1892 , p. 5 .

16. Lignier, O.: Radiculites reticulatus, radicelle fossile de Sequoïnée. Bull. Soc. Bot. France, vol, vi, sér. 4 , 1906, p. 193 .

17. Lindley, J., and Hutton, W.: The Fossil Flora of Great Britain, vol. ii. London, 1833-5. 
18. Potoní, H. : Lehrbuch der Pflanzenpalaeontologie. Berlin, I 899.

19. Renault, B.: Structure comparée de quelques tiges de la Flore Carbonifère. Nouv. Arch. Mus. d'Hist. Nat. Paris, vol. ii, sér. 2, I879, p. 2 I 3.

20. : Cours de Botanique fossile, vol. i. Paris, I 880.

21. : Bassin Houiller et Permien d'Antun et d'Épinac, Flore Fossile, Part ii. Texte 1896, Atlas I893.

22. Renault, B., and Grand'Eury, C. : Étude du Sigillaria spinulosa. Mém. prés. par div. sav. à l'Acad. des Sciences, vol. xxii, I875.

23. Renault, B., and Roche, A. : Sur une nouvelle Diploxylée. Bull. Soc. d'Hist. Nat. d'Autun, vol. $x$ i, 1897 .

24. ScotT, D. H.: Studies in Fossil Botany. London, I900. Second edition, vol. i, I908.

25. - The Structure of Lepidodendron obovatum, Sternb. Ann. Bot., vol. xx, 1906.

26. Seward, A. C. : Notes on the Binney Collection of Coal-Measure Plants. Part i, Lepidophloios. Proc. Phil. Soc. Cambridge, vol. $x$, I899, p. I37.

27. - The Anatomy of Lepidodendron aculeatum, Sternb. Ann. Bot., vol. xx, I906.

28. : Fossil Plants, vol, ii. Cambridge, i 9 Io.

29. Seward, A. C., and Hill, A. W.: On the Structure and Affinities of a Lepidodendroid Stem from the Calciferous Sandstone of Dalmeny, Scotland, possibly identical with Lepidophloios Harcourtii, Witham. Trans. Roy. Soc. Edin., vol. xxxix, Part iv, r900, p. 907.

30. Solms-Laubach, Graf H. zU : Fossil Botany. English edition, Oxford, I89I.

31. TsChirch, A. : Angewandte Pflanzenanatomie. Leipzig, 1889.

32. Watson, D. M. S. : On a Confusion of Two Species under Lepidodendron Harcourtii, Witham, in Williamson's nineteenth Memoir, with a Description of L. Hickii, sp. nov. Mem. Proc. Manchester Lit. Phil. Soc., vol. li, Part iii, I907.

33. Weiss, F. E. : A Biseriate Halonial Branch of Lepidophloios fuliginosus. Trans. Linn. Soc. Bot., ser. 2, vol. vi, I903.

34. - A Probable Parasite of Stigmarian Rootlets. New. Phyt., vol. iii, I904.

35. - The Parichnos in the Lepidodendraceae. Mem. Proc. Manchester Lit. Phil. Soc., vol. li, Part ii, I907.

36. - A Stigmaria with Centripetal Wood. Ann. Bot., vol. xxii, I908.

37. Williamson, W. C. : On the Organization of the Fossil Plants of the Coal Measures, Part ii. Phil. Trans. Roy. Soc., vol. clxii, I872, p. I97.

38. - Ibid., Part iii. Ibid., vol. clxii, I872, p. 283.

39. - Ibid., Part ix. Ibid., vol. clxix, 1878, p. 319 .

40.

41. $:$ Ibid., Part xi. Ibid., vol. clxxii, I88 I, p. 283.

42.

43. - A Monograph on the Morphology and Histology of Stigmaria ficoides. Palaeont. Soc., London, I887.

44. On the Light thrown upon the Question of the Growth and Development of the Carboniferous Arborescent Lepidodendra by a Study of the Details of their Organization. Mem. Proc. Manchester Lit. Phil. Soc., ser. 4, vol. ix, I895.

45. Witham, H. : The Internal Structure of Fossil Vegetables found in the Carboniferous and Oolitic Deposits of Great Britain. Edinburgh, I 833 .

46. ZAlessky, M. D. : On the Internal Structure of the Stem of the Type of Lepidodendron aculeatum, Sternb., and Sigillaria Boblayi, Brongn. Mem. Imp. Russian Min. Soc., vol. xlvi, Part ii, p. 273 , I909.

47. - : Structure du rameau de Lepidodendron obovatum, Sternb., et Note préliminaire sur le Caenoxylon Scotti, nov, gen. et sp. Études paléobotaniques, Part i, St. Petersburg, i 9 I I. 


\section{EXPLANATION OF PLATE XXIV.}

Illustrating Miss Kisch's paper on the Periderm of Fossil Lycopodiales.

(Photographs by Mr. F. Pittock, Zoological Department, University College.)

Fig. I. Transverse section of the periderm of Stigmaria, type I, showing the delicate cells on the inner margin, and at $x$ a cell which has just divided. The short files in the periderm are well seen, and the primary cortex on both sides is preserved. U. C. L. Coll., D $8 . \times 45$.

Fig. 2. Transverse section of the periderm of Stigmaria, type 2, showing the irregular, widecelled outer portion, $a$, the smaller-celled internal portion, $b$, which is broken off towards the interior, the supposed line of the phellogen, $p h$, and the divisions in the cells of the outer cortex as at $c$. U. C. L. Coll., D $8 . \times 45$.

Fig. 3. Colour zones in the periderm of Lepidodendron Scottii caused by differences in the preservation of the cells. U. C. L. Coll., A 4 I . $\times 35$.

Fig. 4. Zones in the periderm of Sigillaria scutellata caused by the smaller size of a few layers of cells. U. C. L. Coll., B II. $\times 35$.

In all cases the peripheral edge of the section is placed uppermost on the plate. 

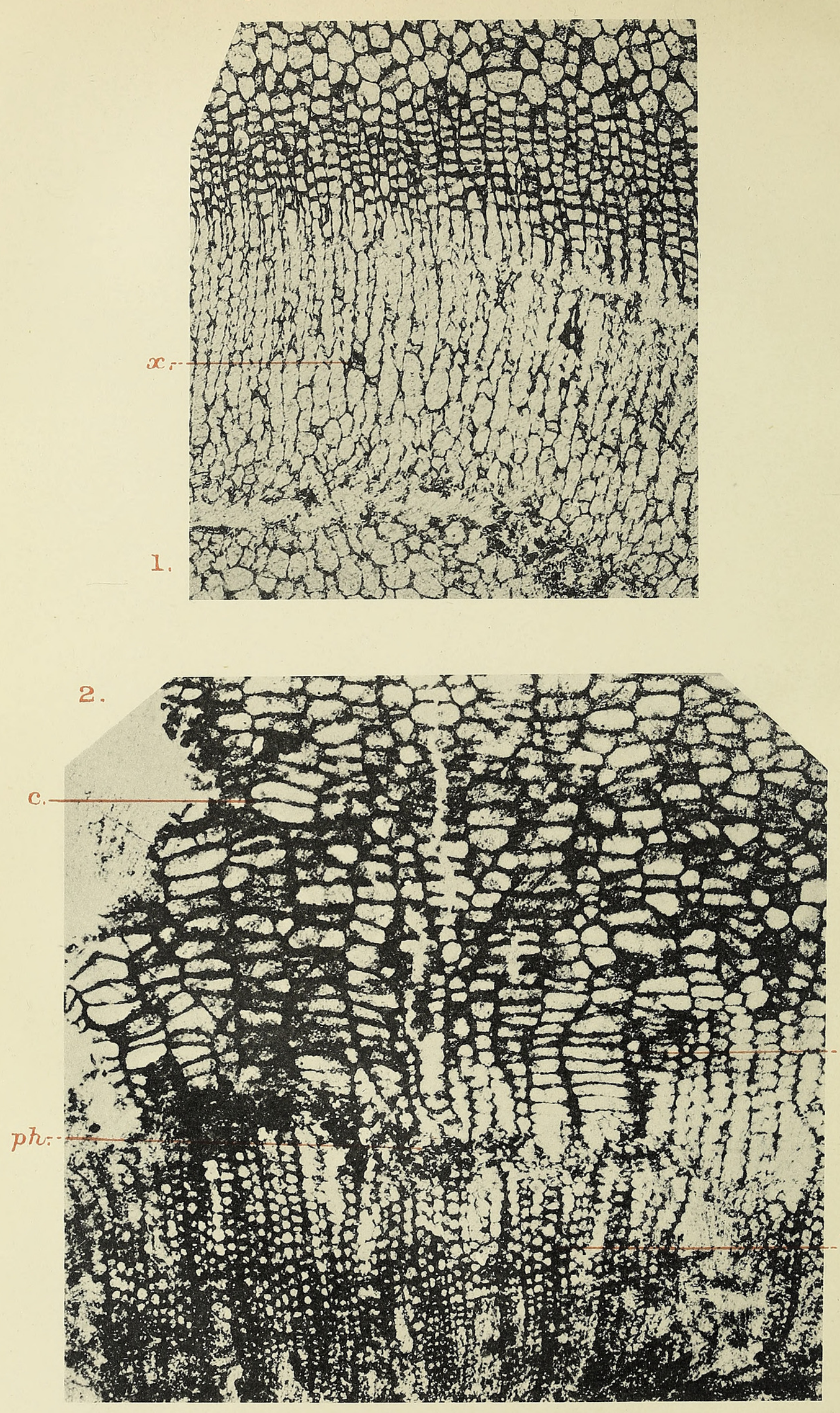

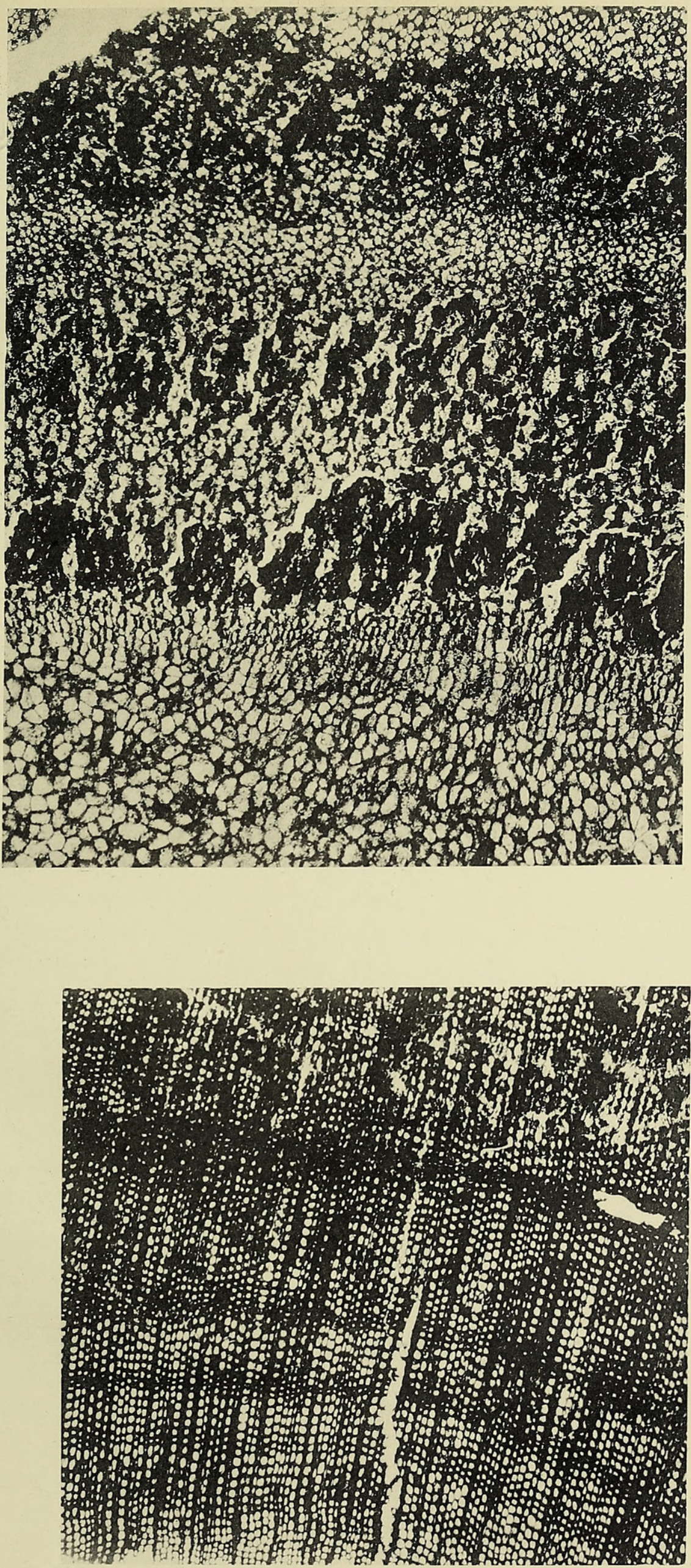


\section{$2 \mathrm{BHL}$ Biodiversity Heritage Library}

Kisch, Mabel H. 1913. "The physiological anatomy of the periderm of fossil Lycopodiales." Annals of botany 27, 281-320.

https://doi.org/10.1093/oxfordjournals.aob.a089460.

View This Item Online: https://www.biodiversitylibrary.org/item/237410

DOI: https://doi.org/10.1093/oxfordjournals.aob.a089460

Permalink: https://www.biodiversitylibrary.org/partpdf/319973

\section{Holding Institution}

Smithsonian Libraries

\section{Sponsored by}

Biodiversity Heritage Library

\section{Copyright \& Reuse}

Copyright Status: Not in copyright. The BHL knows of no copyright restrictions on this item.

This document was created from content at the Biodiversity Heritage Library, the world's largest open access digital library for biodiversity literature and archives. Visit BHL at https://www.biodiversitylibrary.org. 